\title{
UNIFORM VAN DIE STAATSPRESIDENTSWAG - HERKOMS EN TRADISIE
}

\section{Lt kdr E.M. Meyers*}

The origin of the State President's guard with special uniform can be traced back to the early Republican days and the founding of Artillery Corps' by Presidents Brand and Burgers of the Free State and Zuid Afrikaansche Republics, respectively.

To some degree the earliest and later uniforms were based on the ceremonial uniforms of the artillery and therefore these uniforms are discussed and described in detail by the author of this article.

It is also interesting to note the influence of various nations on one another with regard to military uniforms.

The first real State President's Guards wore a green uniform and the author discusses all the changes that it underwent through the years. A blue uniform was inter alia proposed in 1980 but finally rejected by the Prime Minister in 1984. Instructions were issued to put forth new ideas.

All the arguments in favour of a new uniform are discussed in the article and in 1985 the new uniform was finally taken into use. The helmet reminds one of that of the Union Defence Force and the SSB and the uniform itself is that of the Army with a few ceremonial pieces added thereto.

\section{Inleiding}

Die vyfde verjaardag van die Republiek van Suid-Afrika het by verskeie instansies die behoefte aan 'n prestige militêre eenheid asook die heringebruikneming van tradisionele uniforms laat ontstaan. As uitvloeisel daarvan is skrywes tot die destydse Minister van Verdediging en die kommandant-generaal van die Weermag gerig waarin die instelling van ' $n$ militêre wag geklee in spesiale uniforms bepleit is. Die wag moes as seremoniële wag vir die Staatspresident dien en by gepaste geleenthede as erewag optree.

Tot op die stadium was die posisie van die Staatspresident niks meer as 'n blote voortsetting van die amp van Goewerneur-Generaal met 'n naamsverandering nie. Daar is voorts besef dat alles moontlik gedoen moes word om die Staatspresident se beeld groter en waardiger te maak. Aanvanklik het die Staatspresident geen permanente wag gehad nie en sedert die vroeë vyftigerjare het die Leër, Lugmag en Vlootgimnasiums om die beurt as wag eers vir die Goewerneur-Generaal en daarna vir die Staatspresident opgetree. Vervolgens is die Opperbevel van die Weermag versoek om 'n Staatspresidentswag op die been te bring.

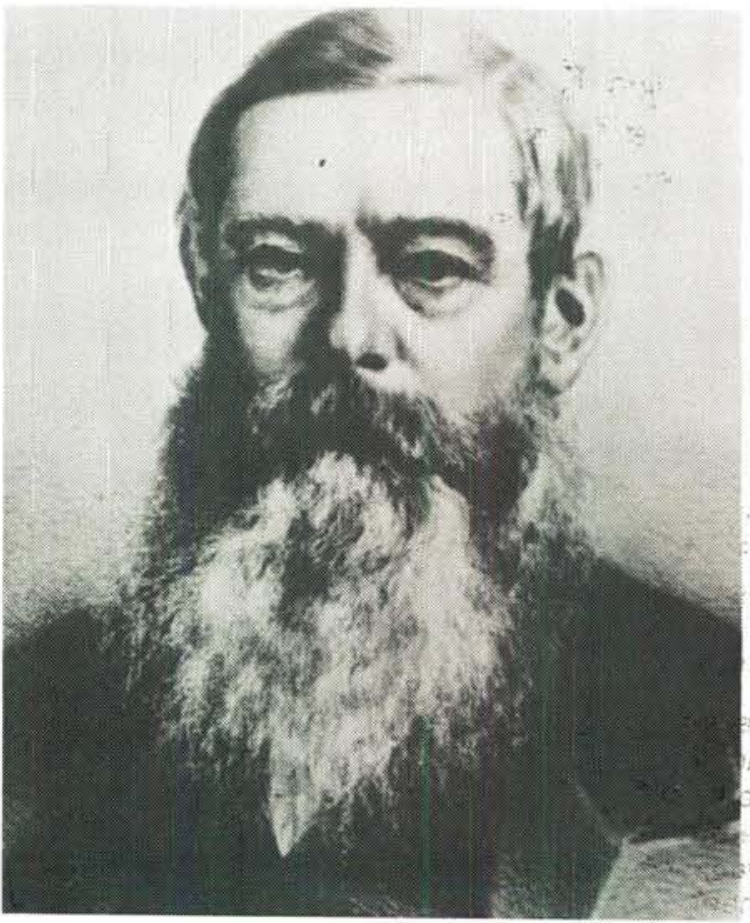

President J.H. Brand, Stigter van die Vrystaatse Artilleriekorps.

President J.H. Brand, founder of the Free State Artillery Corps. 
Die herkoms en die ontstaan van 'n Staatspresidentswag met spesiale uniforms hier te lande kan teruggevoer word na die vroeë Republikeinse dae met die stigting van die artilleriekorpse deur Presidente Brand en Burgers van die Vrystaatse en Zuid-Afrikaansche Republieke, onderskeidelik.

Die vorm van die eerste en latere uniforms van die Staatspresidentswag was in 'n mate gebaseer op seremoniële uniforms van die artillerie in sowel die negentiende eeuse Oranje-Vrystaat as die ou Zuid-Afrikaansche Republiek. Om hierdie rede word die verskillende uniforms en hul variasies breedvoerig bespreek.

Wanneer die herkoms van 'n militêre uniform bestudeer word, is dit interessant om te let op die invloed wat sommige nasies op mekaar uitgeoefen het.

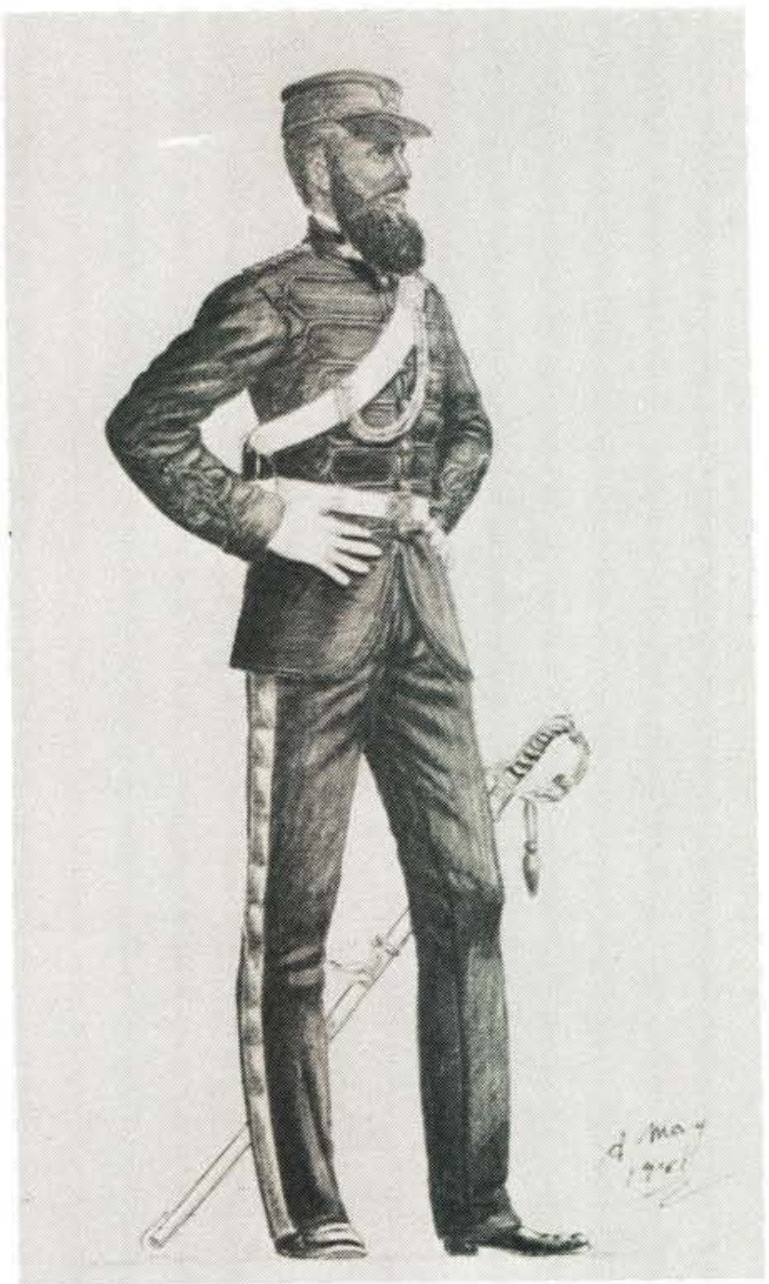

Luitenant OVS Staatsartillerie in 1870 in vroegste uniform.

A lieutenant of the OFS State Artillery in 1870 wearing the earliest uniform.
Die helmet wat bv in die Pruisiese Weermag gedra is, kan teruggevoer word na Engeland, Oostenryk, Swede, die VSA, Meksiko, Columbië en Bolivië. Sekere militêre historici beweer dat die punthelmet oorgeneem is van Tsaar Nicholas van Rusland en dat Frederik Willem dit as 'n prototipe gesien het tydens sy besoek aan die keiser. By sy terugkeer in Pruise het hy dit as uniformstuk vir sy troepe aanvaar.

\section{Vrystaatse Artilleriekorps}

Hoewel die ontdekking van diamante en die anneksasie wat daarop gevolg het as spoorslag gedien het om die artilleriekorps op te knap, is daar eers in 1875 werklike pogings aangewend om die korps op ' $n$ beter grondslag te plaas.

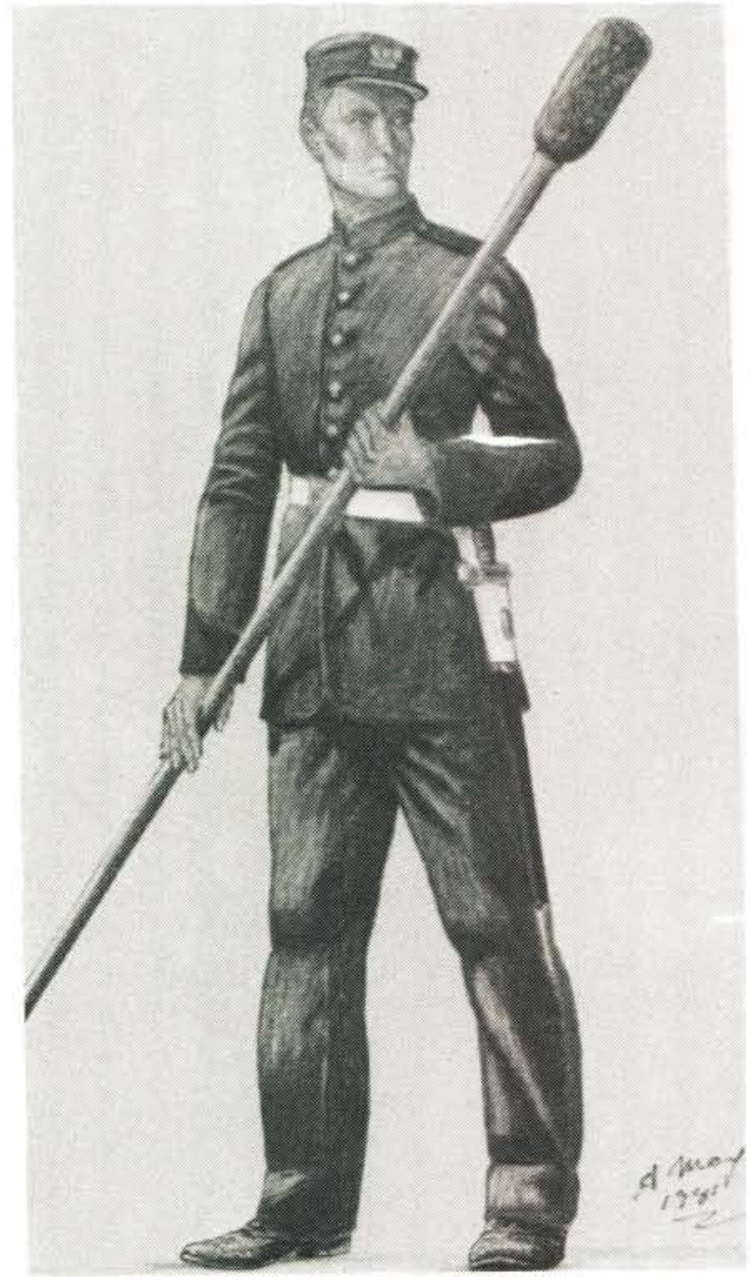

Bombardier in eerste uniform van OVS se Artillerie in 1870.

A bombardier wearing the first uniform of the OFS Artillery in 1870. 


\section{Rol van die Staatspresident}

Met sy strenge organisasie het President Brand gepoog om die korps tot 'n prestige militêre eenheid uit te bou. Die artilleriekorps het onder direkte beheer van die Staatspresident en van die bevelvoerende kommandant van die leërafdeling gestaan. Ten tye van oorlog en kommando kon die Staatspresident benoeminge van offi-

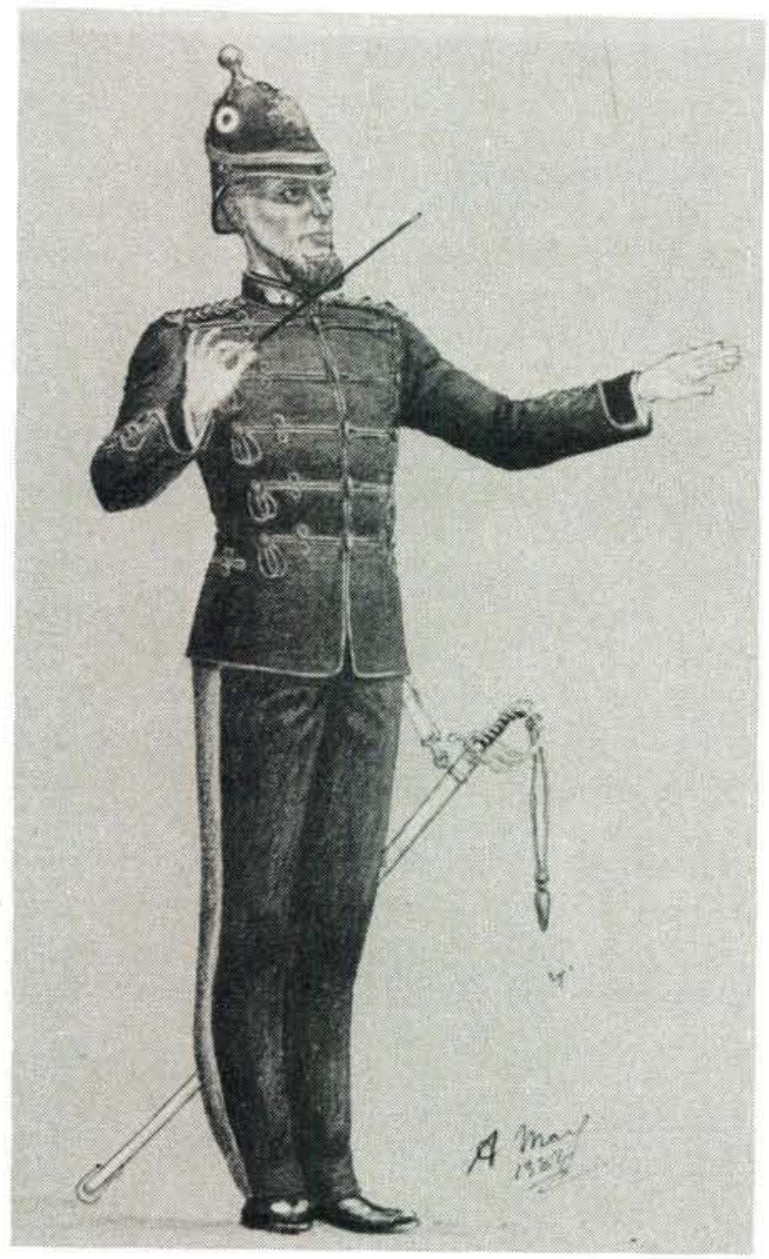

Orkesmeester van die Vrystaatse Artillerie 1880-90 in tweede uniform vanaf die Britse patroon oorgeneem.

A band leader of the OFS State Artillery during 1880-90, wearing the second uniform which was based on the British pattern.

siere doen. Hy het ook die uniforms en wysigings daarvan bepaal en gesorg dat artilleriste nie net militêre opleiding ontvang nie, maar daagliks in gewone skolastiese vakke onderrig word.

\section{Vereistes}

Regulasies wat in 1876 vir die Vrystaatse artil- leriste vasgelê is, het hulle vir drie jaar, waarin hulle nie toegelaat is om te trou nie, tot aktiewe diens verbind. Hulle moes tussen 16 en 20 jaar oud wees, toestemming van hul ouers of voogde gehad het om by die korps aan te sluit en fisies gesond wees. Verder moes hulle 'n edel karakter hê, godsdiensoefeninge bywoon en sorg dra dat hulle wapens, saals en tooms gedurig in orde is.

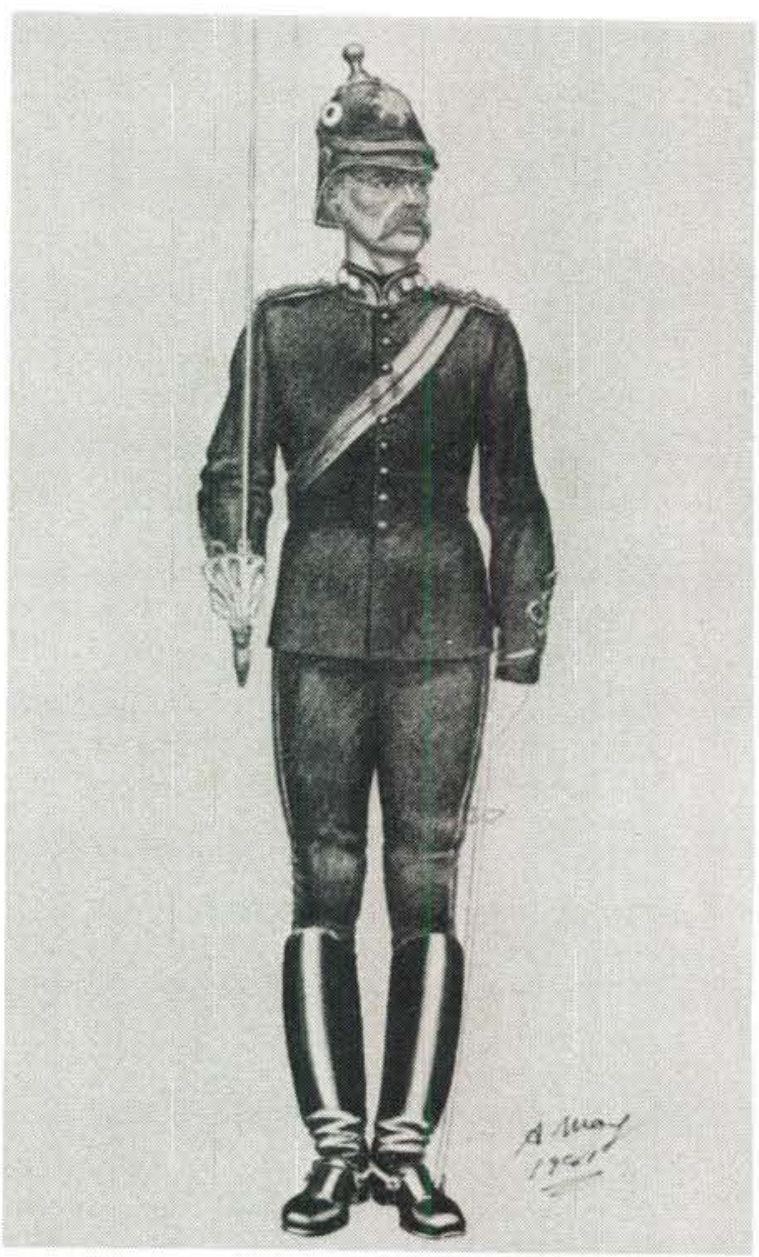

Offisier in die Vrystaatse Artillerie op parade 1880-90 Tweede uniform van Britse tipe.

An officer in the OFS Artillery on parade 1880-90. He is wearing the second uniform of the British type.

\section{Uniforms en wysigings daarvan}

Die herkoms en tradisie van 'n Staatspresidentswag is direk herleibaar vanaf dié van die Vrystaatse Artillerie. Deur die ontstaan, ontwikkeling en voortdurende wysigings van hierdie uniform in oënskou te neem, kan die ontwerp en wysigings van die Staatpresidentswag se uniform verstaan en verklaar word. 
Hoewel die Republikeinse krygsmagte nooit 'n uniform tydens kommandodiens gedra het nie, het president Brand gesorg dat die Vrystaatse Artilleriekorps sedert sy ontstaan met uniforms toegerus is. Die uniforms het aanvanklik 'n Britse voorkoms gehad, tog het dit deurentyd van voorkoms verander. Met die koms van die Pruisiese offisier, R.F.W. Albrecht het die uniform sowel as die helmet 'n Duitse karakter gekry.

Die materiaal waaruit die uniform in 1876 gemaak is, het uit blou laken en blou serge bestaan. Geen omskrywing van die vroeë uniform word gevind nie. Tog word daar melding gemaak van rooi koordbroeke, koordbaadjies, bruin Bedford koord, swart slyt koord en flennie.

\section{Offisiere se uniform}

In Oktober 1880 is besluit om nuwe uniforms vir die korps te ontwerp. Gevolglik het die uniforms in snit en voorkoms met dié van die Royal Artillery ooreengekom. Dit was egter donkerblou van kleur, van oranje belegsel voorsien en die kraag en moue is met goue koord opgemaak. Die broek was van dieselfde materiaal en kleur met 'n breë goue streep langs die naat. By die groottenue het alle offisiere donkerblou kwartierpette gedra, voorsien van 'n band met goue kant en

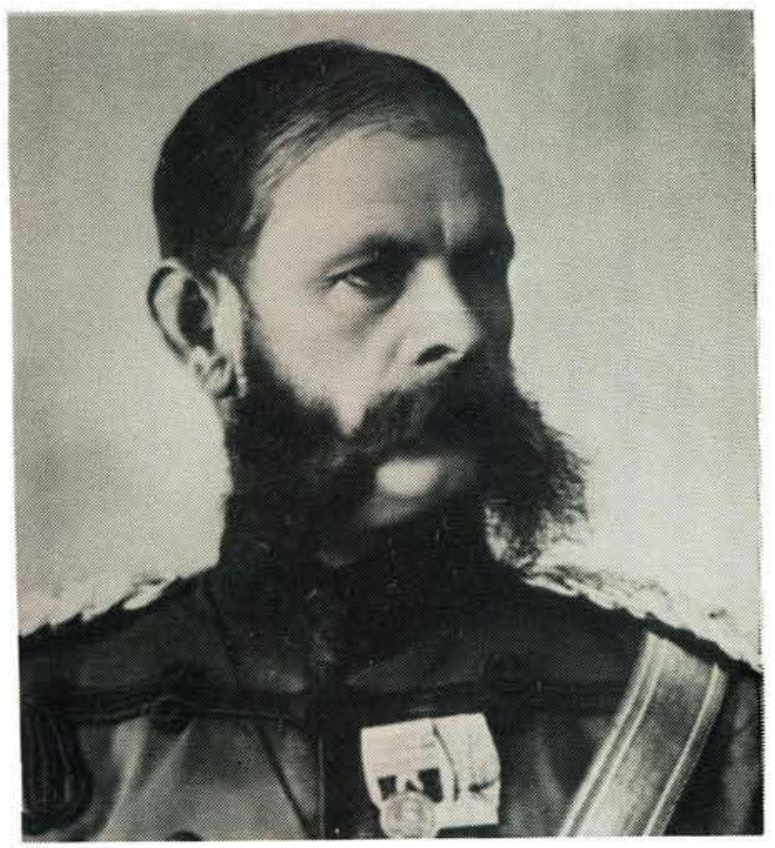

Kapt R.F.W. Albrecht, bevelvoerder van die Vrystaatse Artillerie.

Capt R.F.W. Albrecht, officer commanding of the OFS Artillery. wit en oranjekleurige kokardes en 'n Vrystaatse wapen op die voorkant van die pet. Hierdie uniform was met 'n swaard gedra.

Die kleintenue van offisiere was van blou serge met swart belegsel. Die broeke was van dieselfde materiaal gemaak, maar met swart kant op die buite nate van die broek. Offisiere het helmets hierby gedra wat soos dié van die Royal Artillery gelyk het, hoewel die helmets later 'n Pruisiese karakter aangeneem het. By die groottenue is 'n slap verebos aan die knop van die helmet gedra. Die nuutste hoofbedekking van die Staatspresidentseenheid is ook die wit helmet met die wapen van die Republiek voorop.

Die offisiere van die Vrystaatse Artillerie is elk voorsien van Marokko skouerbande bedek met goue kant, wit lyfbande met 'n vergulde plaat, swart bandeliers met vergulde versiering en die Vrystaatse wapen. Die skouerbande is voorsien van silwer klosse.

\section{Uniform van manskappe}

Die groottenue van die manskappe was basies dieselfde snit en van dieselfde materiaal as die van die offisiere, maar met oranjekleurige versiersels op die kraag en moue.

Die manskappe se kleintenue hierteenoor is gemaak van bruin wollerige bedfordkoord met ' $n$ swart kraag. Die moue is met swart koord versier. As hoofbedekking het hulle blou helmets gedra asook pette wat volgens die snit van die Franse Infanterie gemaak is, versier met swart bande en swart koord.

\section{R.F.W. Albrecht}

Die uniforms het nie hierdie voorkoms behou nie, maar is gerekonstrueer deur Albrecht. In 1885 het die groottenue van offisiere uit een pet en een tuniek bestaan. Alles is van blou laken gemaak en versier met goue koord. Blykbaar het die artilleriste wit uniforms gedra wat op parade en tydens staldiens gedra moes word. Dit het egter al meer in onguns geraak en die Volksraad het besluit om na die vroeëre soort uniforms terug te gaan sodra die artillerie weer uniforms moes kry.

Alhoewel President Brand gepoog het om die artilleriekorps gedurende sy wordingsjare op 'n vaste basis te plaas, het die korps eers in 1880 met die koms van Albrecht 'n streng militêre karakter aangeneem. Kaptein Albrecht wou die soldatestand tot erestand verhef en het nie net 


\section{OVS STAATSARTILLERIE}

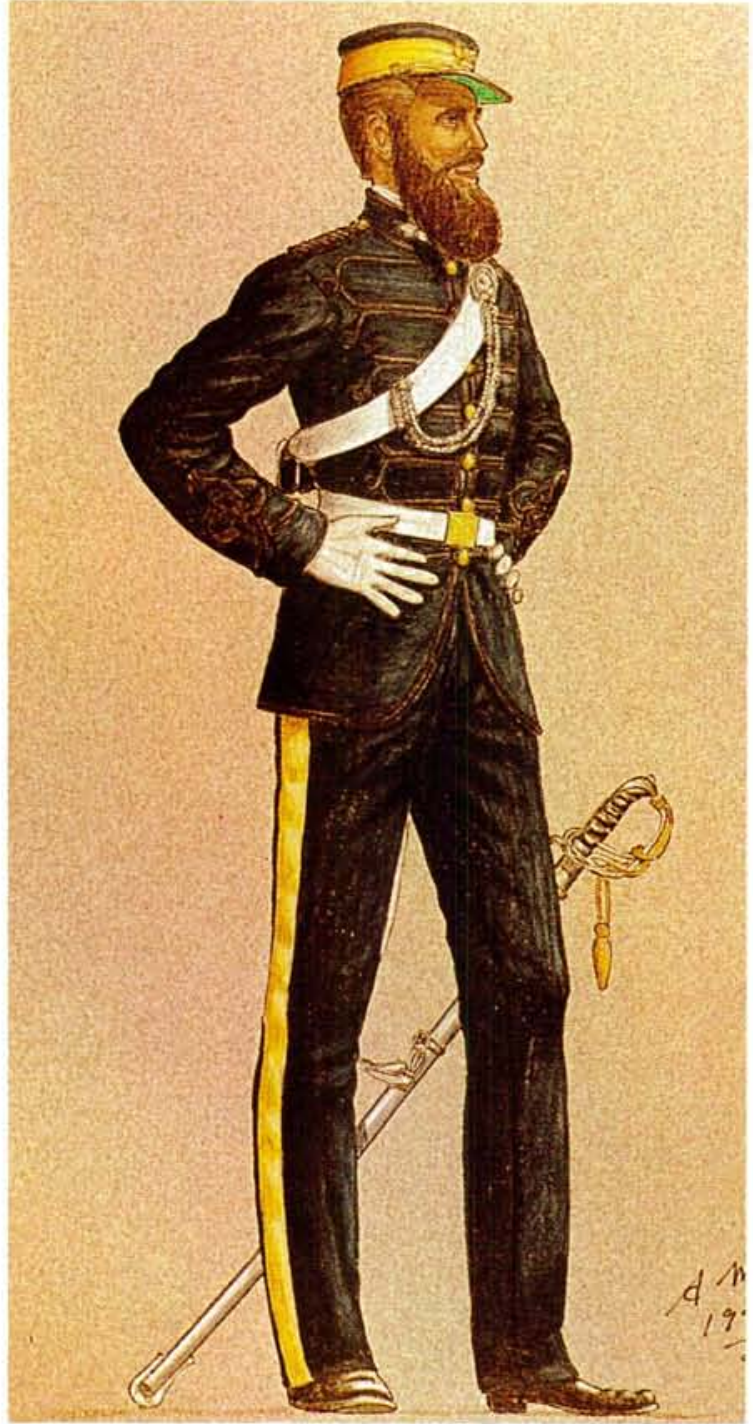

'n Luitenant in die Velddrag van die OVS staatsartillerie. Die tweede patroon is in 1880-90 gedra.

A lieutenant in the field kit of the OFS State Artillery. The second pattern was adopted in

$$
1880-90 .
$$

\section{'n Luitenant van die OVS Staatsartillerie in 1870 in die eerste uniform.}

A lieutenant of the OFS State Artillery in 1870 wearing the earliest uniform.

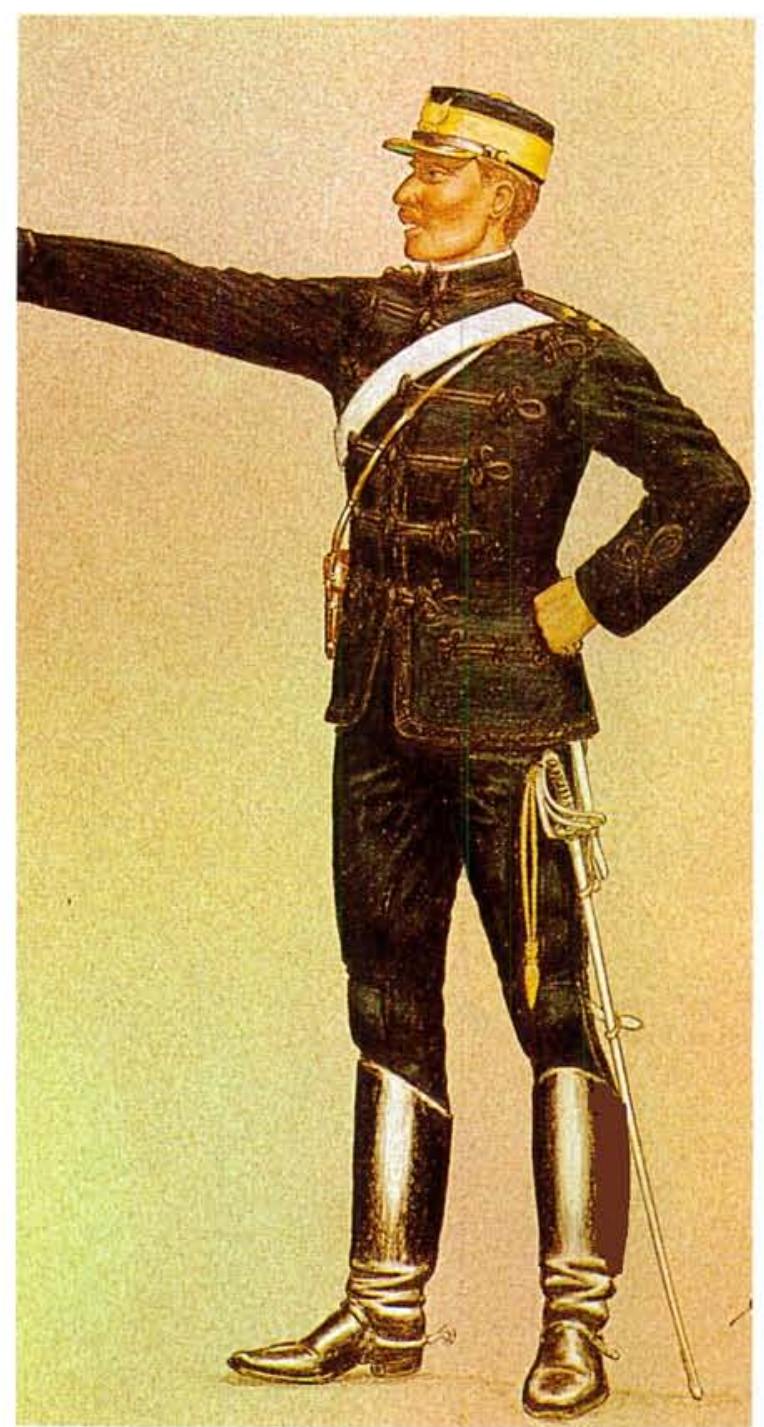




\section{OFS STATE ARTILLERY}

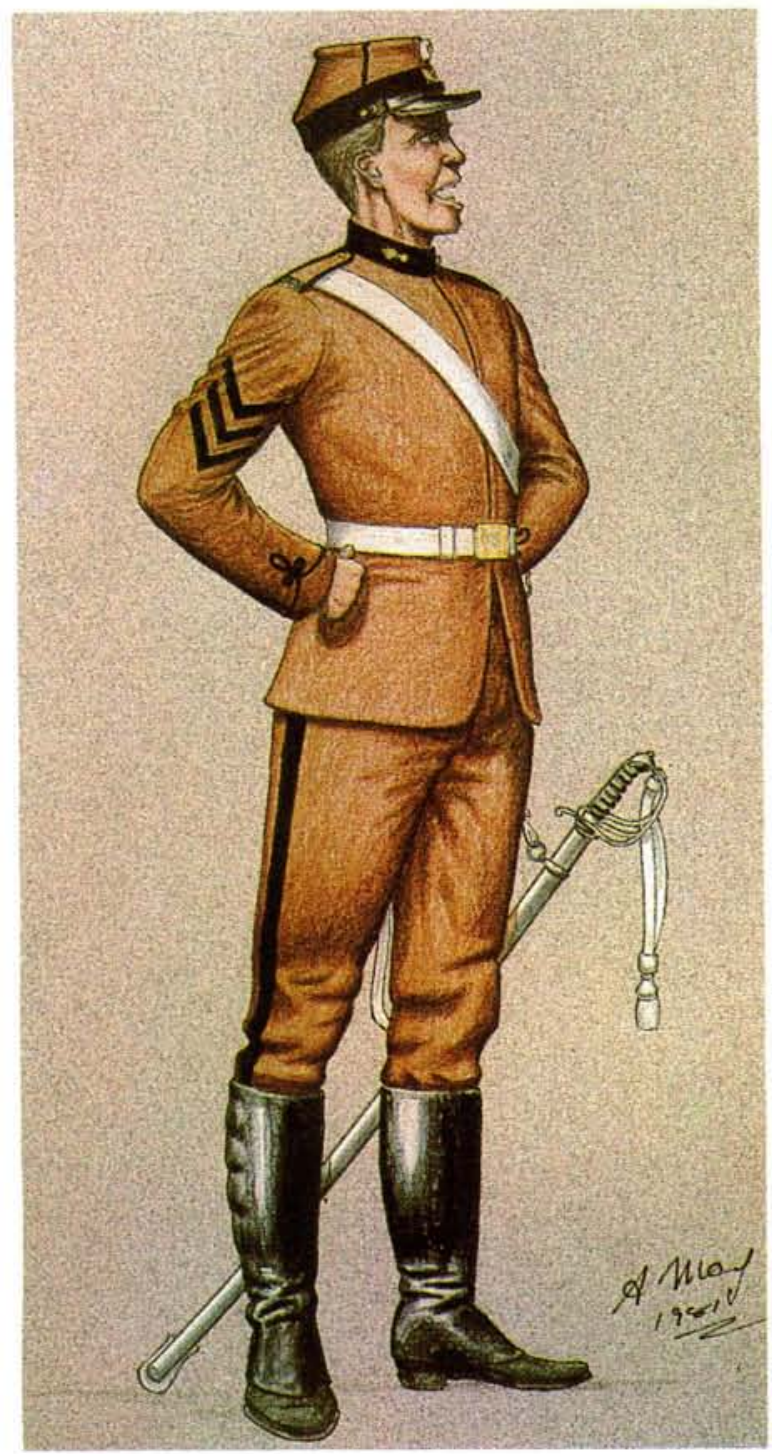
'n Sersant dra die ou republikeinse velddrag tussen 1880-90. Die tweede uniform van die OVS Staatsartillerie.

A sergeant wearing the old republican field service dress between 1880-90. The second uniform of the OFS State Artillery.

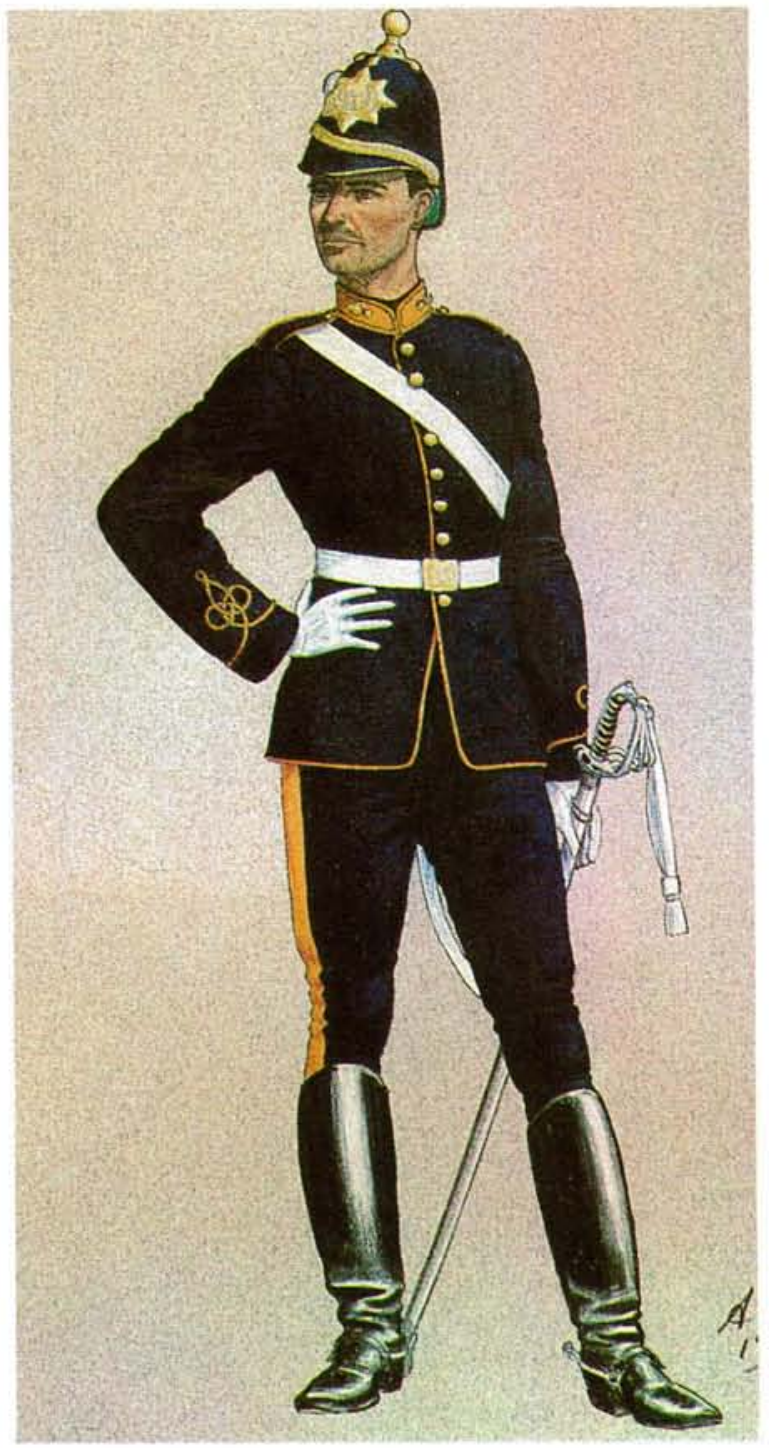

\section{'n OVS Staatsartillerie artilleris in volle mondering} aangeneem en gedra tussen 1880-90.

An OFS State Artillery Gunner in full dress adopted and introduced between 1880-90. 
die moreel nie, maar ook hul opleidingsprogram opgeknap. Die korps is versterk van 41 na 100 manskappe en salarisse is verhoog. Dit sou moes verhoed dat artilleriste by die ZAR se staatsartillerie aansluit.

Die korps het by die dag gegroei en President Brand kon nie nalaat om met groot lof van die kaptein te praat nie. Op 14 Julie 1888 is President Brand, stigter en vroeëre hoof van die korps oorlede. 'n Militêre begrafnis waaraan die Vrystaatse artillerie deelgeneem het, is georganiseer.

Die Vrystaatse artilleriekorps is nie alleen tot 'n nasionale onafhanklike mag opgebou nie, maar 'n Berede Diensmag wat polisie funksies sou vervul, is uit die geledere van die artilleriste saamgestel.

\section{Die Transvaalse Staatsartillerie}

Die hoofbedekking van die Staatspresidentswag was nie altyd dieselfde nie, maar het baie variasies beleef. Die eerste wag het 'n mus gedra waarvan die oorsprong die Staatsartillerie kon wees.

\section{Oorsprong}

Die artilleriekorps van die Zuid-Afrikaansche Republiek het sy oorsprong aan president T.F. Burgers te danke gehad. Om die artilleriekorps te help oprig, het President Burgers 'n Duitse offisier, kaptein Otto Riedl gewerf. Die president het ook veel gedoen tov die aankweking van 'n militêre gees asook 'n bewuste vaderlandsliefde by die korps.

In die grondwetwysiginge wat in 1877 aanvaar is, is die eerste keer in die geskiedenis van die ZAR melding van ' $n$ artilleriekorps gemaak. Die republiek het trouens nooit 'n ander vorm van staandemag geken nie. Hierdie korps het aanvanklik as die "Battery Dingaan" bekend gestaan.

\section{Anneksasie}

Die eenheid het tydens die eerste anneksasie verdwyn, hoewel 'n republikeinse artilleriekorps in 1881 met die herstel van die republiek heropgerig is.

\section{Eerste Vryheidsoorlog}

$\mathrm{Na}$ die eerste Vryheidsoorlog is daar andermaal 'n begin gemaak met die heropbou van die artilleriekorps en in September 1881 het kmdt-genl P.J. Joubert 'n artilleriekorps soortgelyk aan die van die Vrystaat gestig.

\section{H.P.N. Pretorius}

$\mathrm{Na}$ verskillende naamsveranderinge en reorganisasie het die eenheid in die tagtigerjare ' $n$ artilleriekorps in die ware sin van die woord geword nadat die eenheid met die berede polisie ver-

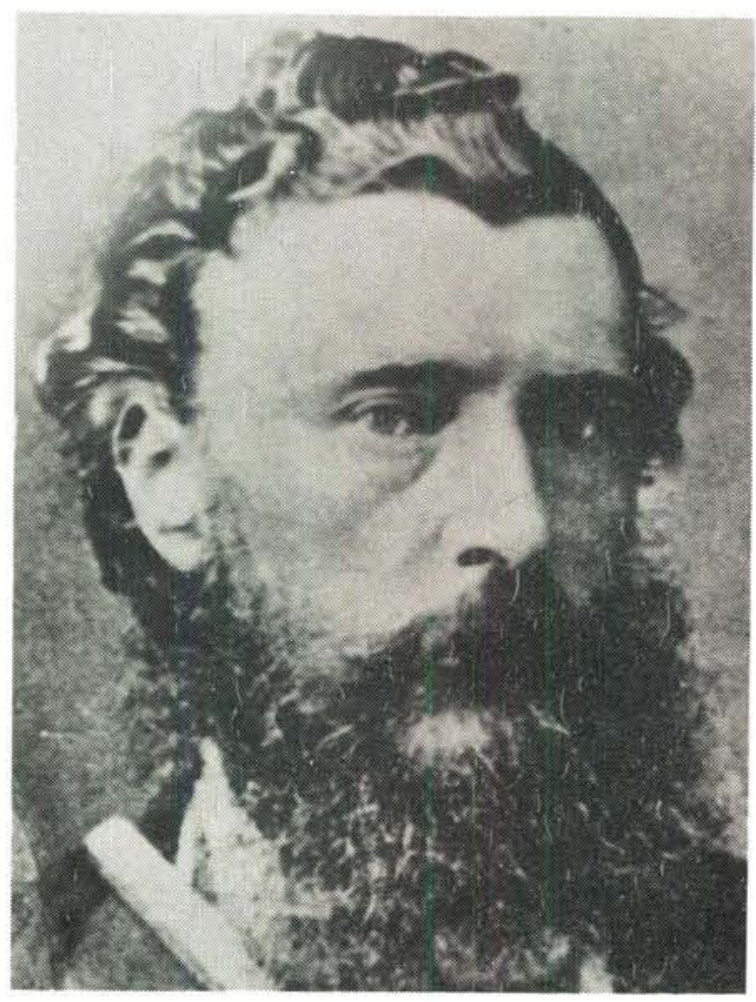

Henning Pretorius, vader en eerste kommandant van die Staatsartillerie. In 1896 is die rang van kommandant van die Staatsartillerie verhoog tot die van luitenant-kolonel.

Henning Pretorius, father and first commandant of the State Artillery. In 1896 the rank of commandant of the State Artillery was raised to that of lieutenant-colonel.

breek is. Met die afsterwe van die "Vader van die Staatsartillerie", H.P.N. Pretorius, is hy opgevolg deur S.P.E. Trichardt wat hoof van die Staatsartillerie was totdat dit opgehou het om te bestaan. 


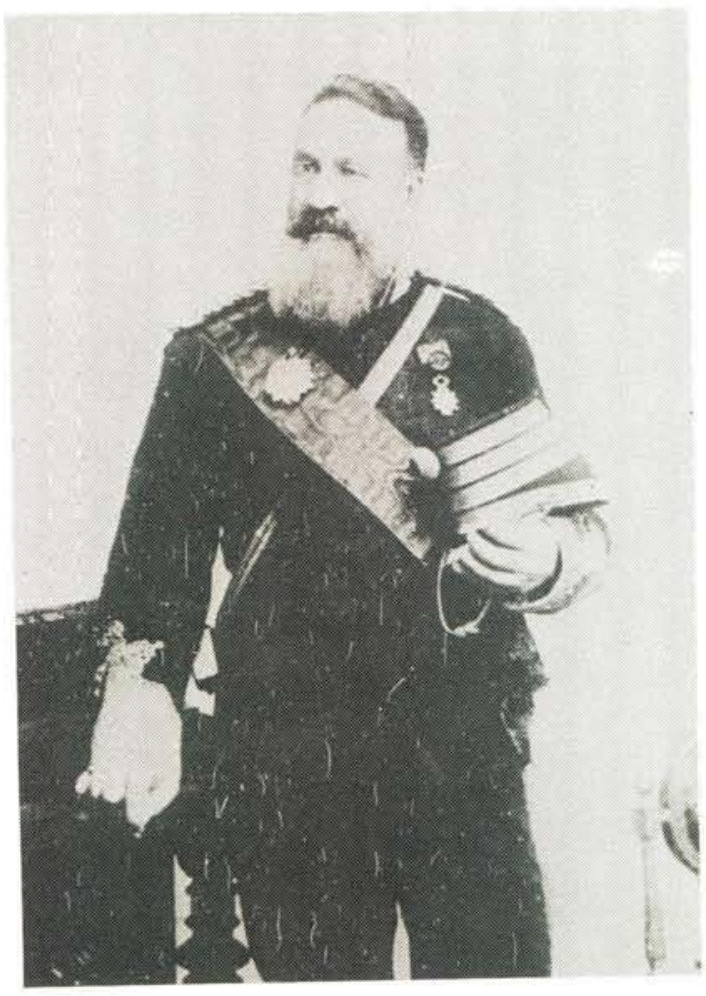

President T.F. Burgers, stigter van die Transvaalse Staatsan'illerie.

President T.F. Burgers, founder of the Transvaal State Artillery.

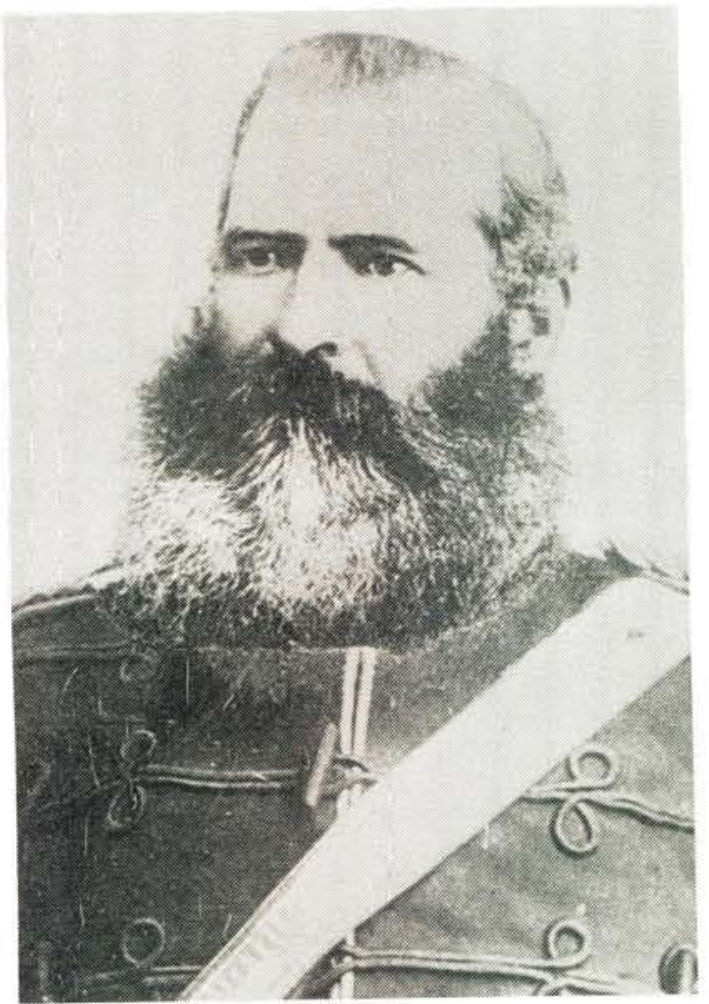

Genl Piet Joubert, Transvaalse kommandant-generaal. General Piet Joubert, the Transvaal CommandantGeneral.

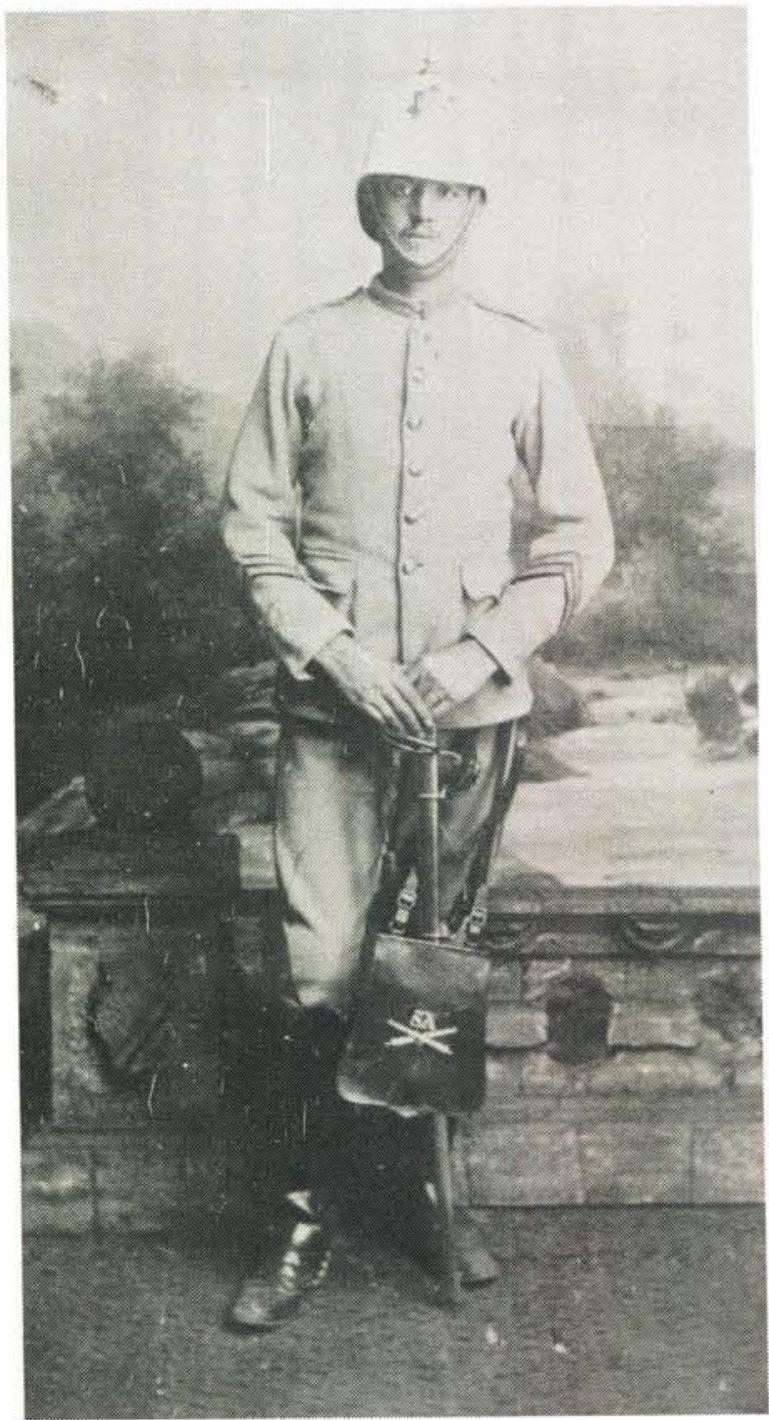

Somer of velddiens uniform van 'n wagmeester in die Staatsartillerie met wit helmet.

Summer or field service dress, with white helmet, of a battery sergeant-major of the State Artillery.

\section{Bevel en leierskap}

Die Staatsartillerie was soos vandag se Staatspresidentseenheid onder die opperbevel van die staatshoof, wat toe die kommandant-generaal was. Die aanvoerder van die Staatsartillerie was 'n "Overste Commandant" of 'n "Luitenantkolonel".

\section{Vereistes}

Die vereistes vir lede van die korps was dat hulle gewerf moes word uit gebore en genaturaliseerde burgers van die Suid-Afrikaansche Republiek; hulle moes minstens 16 jaar oud wees; ongetroud wees; as liggaamlik geskik deur 'n geneesheer aanbeveel word en laastens op grond van goeie gedrag kwalifiseer. 


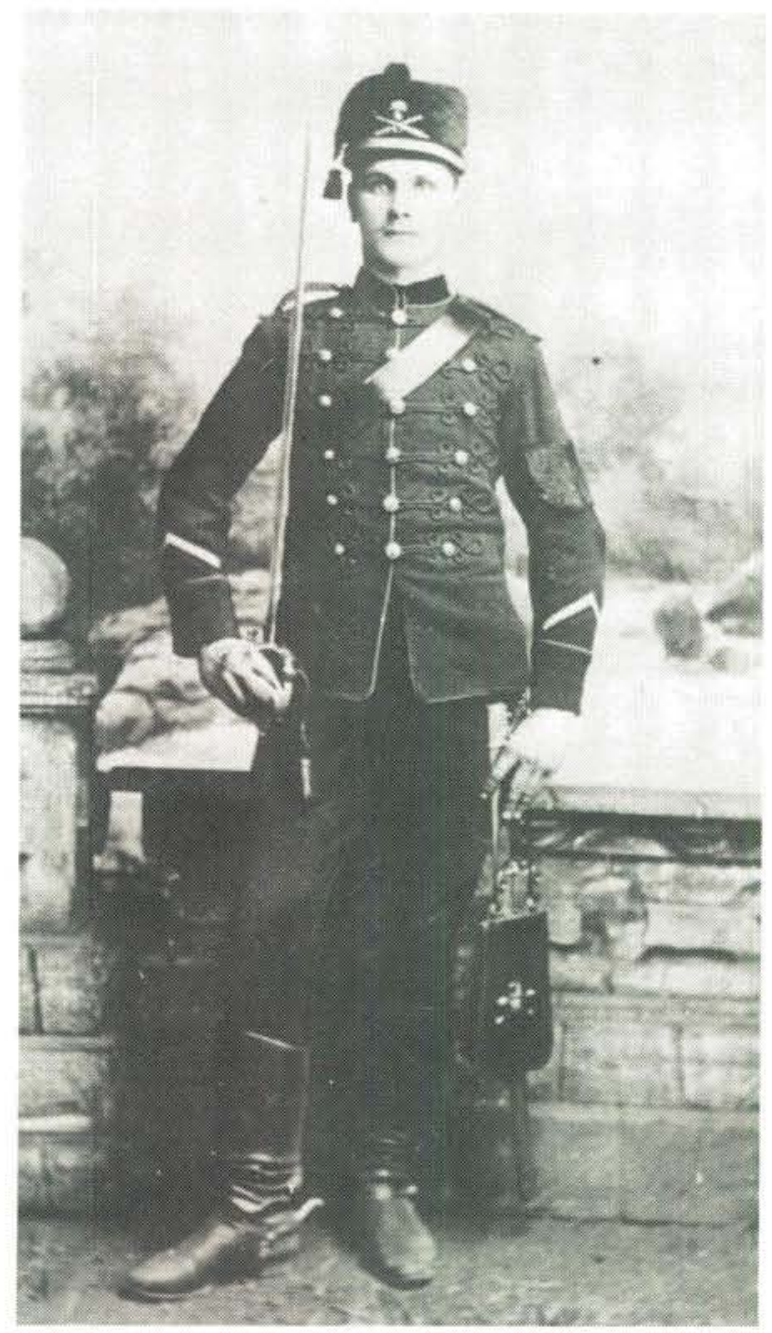

Winter of Parade uniform van 'n korporaal.

Winter dress or parade dress of a corporal.

\section{Uniform}

In die tagtigerjare was die artillerie se kleredrag ' $n$ mengelmoes van uniform en burgerlike klere. Twee tipes uniform is gedra $\mathrm{nl}$ ' $\mathrm{n}$ velddiens of someruniform wat van ' $n$ sandkleurige materiaal vervaardig is en 'n donkerblou parade of winteruniform wat met koringblou omgeboor was. Eersgenoemde uniform bestaan uit ' $n$ baadjie met 'n toegeknoopte kraag en skouerstukke, bronsknope, rybroek en hoë rystewels met spore.

Die hoofbedekking was ' $n$ wit helmet met helmetpen en 'n slap verebos, maar een battery het 'n husaremus gedra wat waarskynlik na die husaremus van die Nederlandse leër gemaak is.
Die parade uniform het heelwat meer versierings as die velddiensuniform gehad, onder meer drie rye van ses knope elk, regopstaande wit kwaste op die sierlike mus en rye sierkoord in mooi

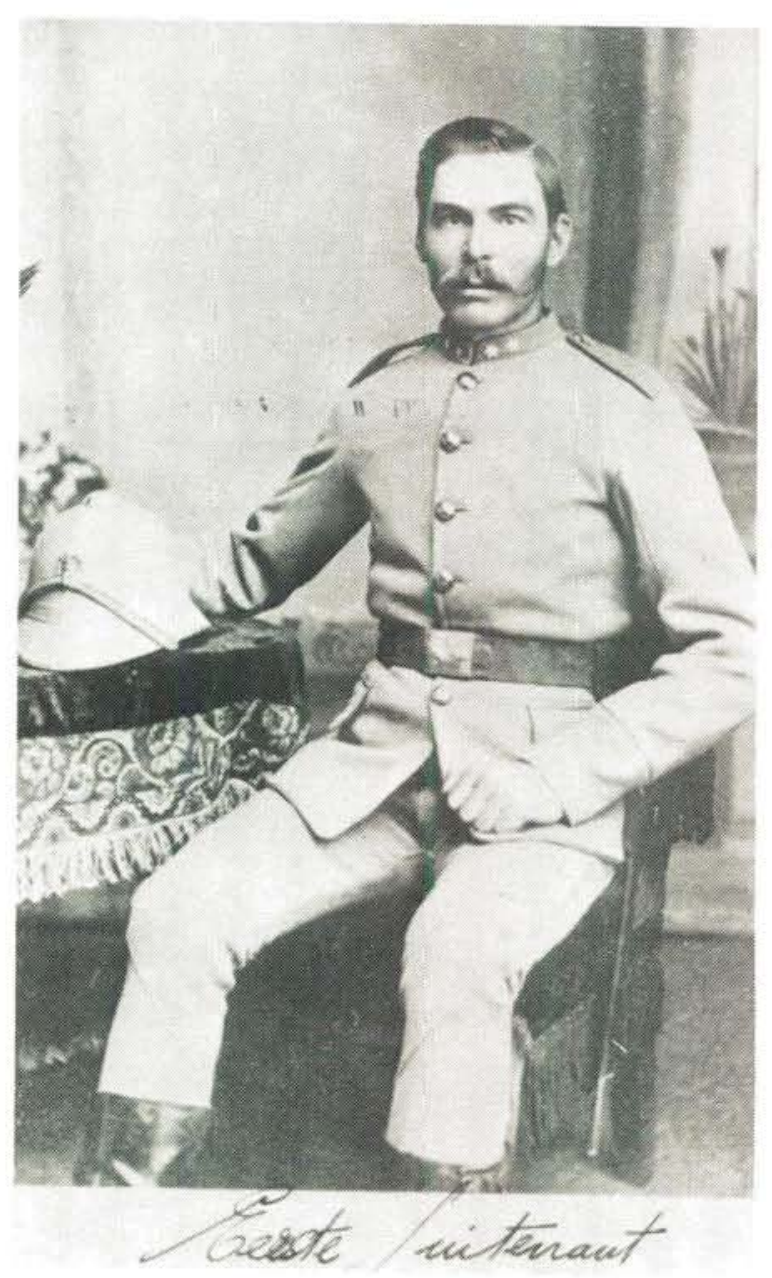

Winteruniform. Let op helmet met wit pluim. Winter dress. Note the helmet with white plume.

patrone oor die borsstuk van die uniform vasgewerk. Hierdie uniform was egter onprakties as gevegsdrag.

\section{Bewapening}

Elke artilleris het ' $n$ sabel gedra bykomstig by die res van sy bewapening wat deur Wet No 1 van 1896 soos volg bepaal is:

(a) Offisiere en adjudant-offisiere - 'n rewolwer en verkyker.

(b) Onder-offisiere - 'n karabyn en verkyker.

(c) Trompetters - 'n rewolwer.

(d) Manskappe - 'n karabyn.

(e) Veldtelegrafiste - 'n karabyn en verkyker. 


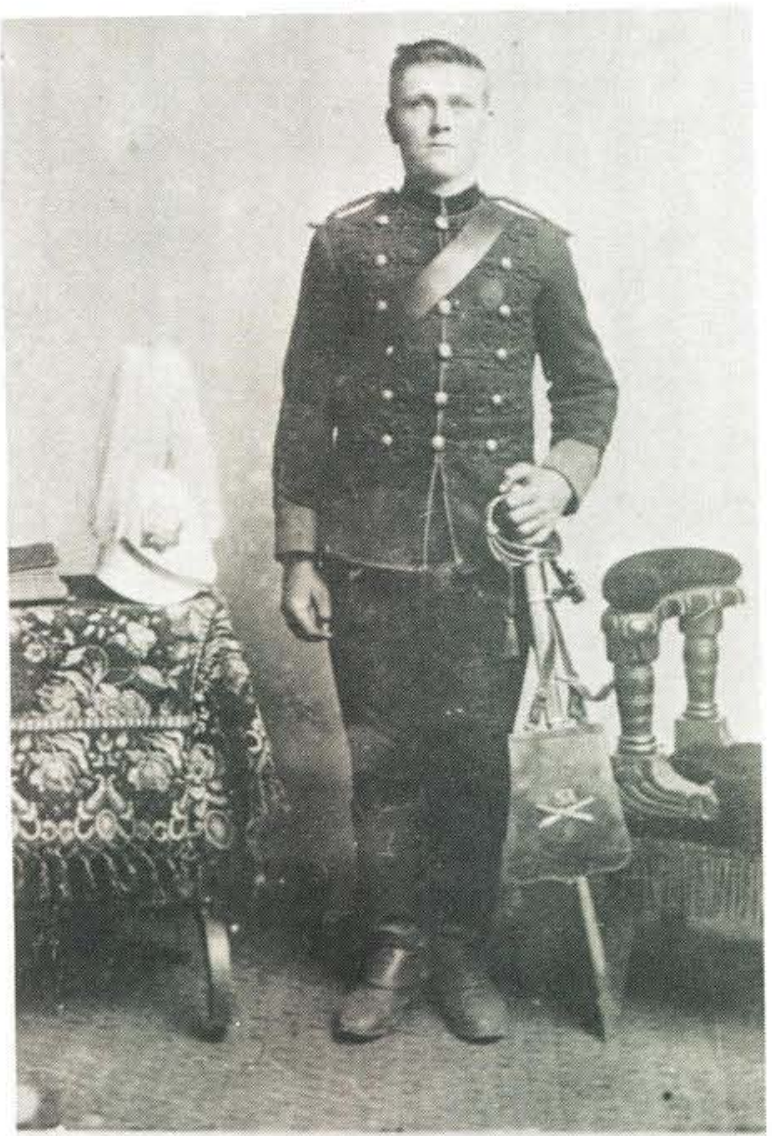

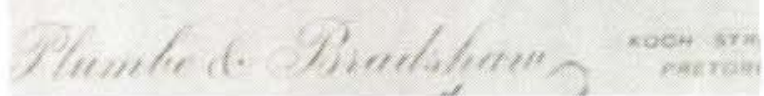

Somer velddiens uniform van 'n offisier in die Staatsartillerie. Elke artilleris was nog met 'n sabel bewapen.

Summer dress or field dress of an officer of the State Artillery. Each gunner was armed with a sword.

(f) Musikante - 'n degen en rewolwer. (Hierdie was die enigste wat nie sabels gedra het nie).

\section{Tweede Vryheidsoorlog}

Die Staatsartillerie het 'n leeue-aandeel gehad in die Tweede Vryheidsoorlog by oa Mafeking, die Slag van Talanaheuwel en van Elandslaagte, die geveg by Modderspruit, die beleg van Ladysmith, Colenso, Spioenkop, Paardeberg en Kimberley asook die laaste stellingsgeveg van die oorlog by Bergendal. (Dalmanutha)

Met die ondertekening van die Vrede van Vereeniging op 31 Mei 1902 het die Suid-Afrikaanse Republiek en daarmee saam die Staatsartillerie opgehou bestaan.

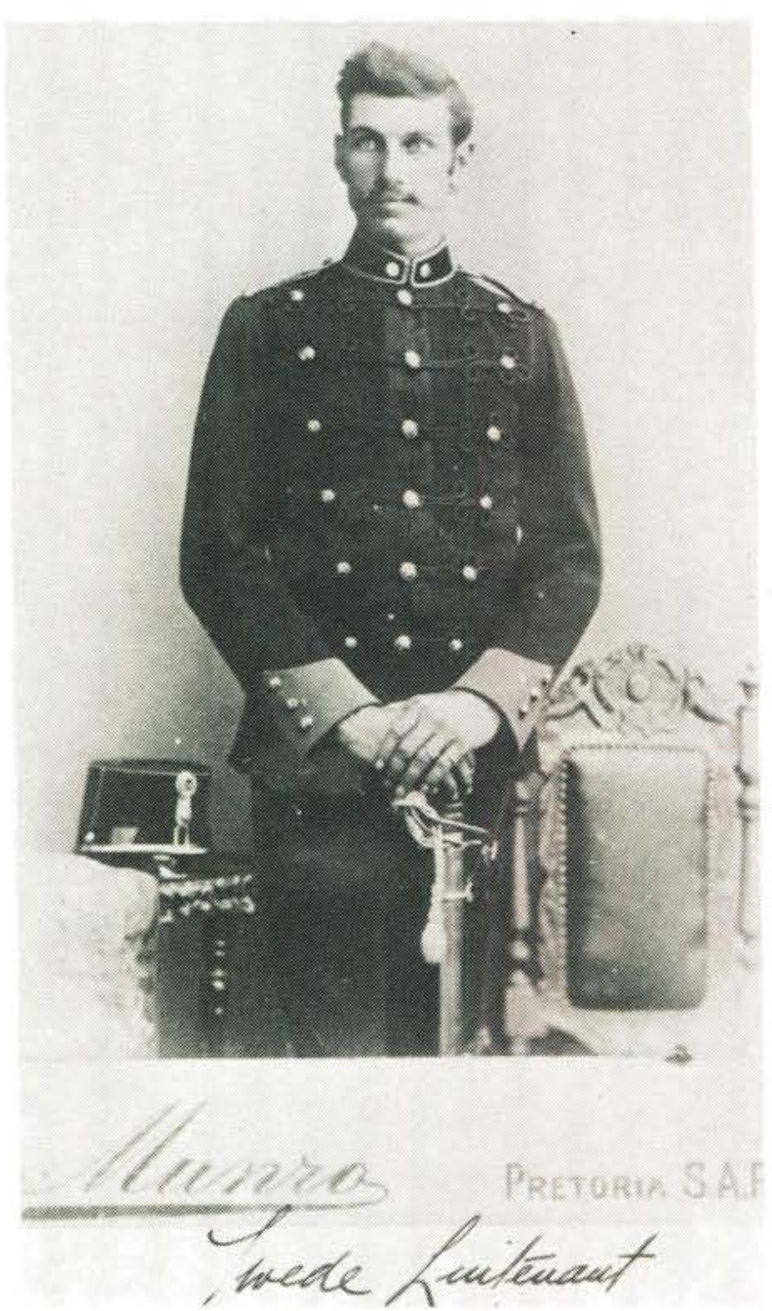

Winteruniform van ' $n$ offisier. Let op pet as hoofbedekking.

Winter dress of an officer. Note the hat as head-gear.

\section{Staatspresidentswag}

Met die oorspronklike instelling van die Staatspresidentswag is besluit om 'n spesiale uniform te ontwerp vir die beplande inhuldiging van Dr Dönges as Staatspresident op Republiekdag 1967. Aangesien daar genoeg materiaal in voorraad was om die nodige seremoniële uniforms van die Staatspresidentswag te vervaardig, is ook besluit op ' $n$ uniformontwerp waarby die beskikbare groen materiaal gebruik sou kon word. Die swart Leërgimnasiumpet met die.Republiekwapen voorop en goue tooisels rondom aangebring, sou gedra word.

\section{Groen uniform}

Die vorm van die eerste en latere uniforms was 
in 'n mate gebaseer op seremoniële uniforms van die artillerie in sowel die negentiende eeuse Oranje-Vrystaat as die ou Zuid-Afrikaansche Republiek. Veral die vorm van hooftooisel was hierop gebasseer, hoewel die SP Wag swart volstruisvere in plaas van haanvere gebruik het.

Die patroon van die traseergalon op die bors van die baadjie van die tweede en derde uniforms, en op die skouers van al drie ontwerpe, kan ook na die ou republikeinse uniforms teruggevoer word, en so ook die snit van die tweede

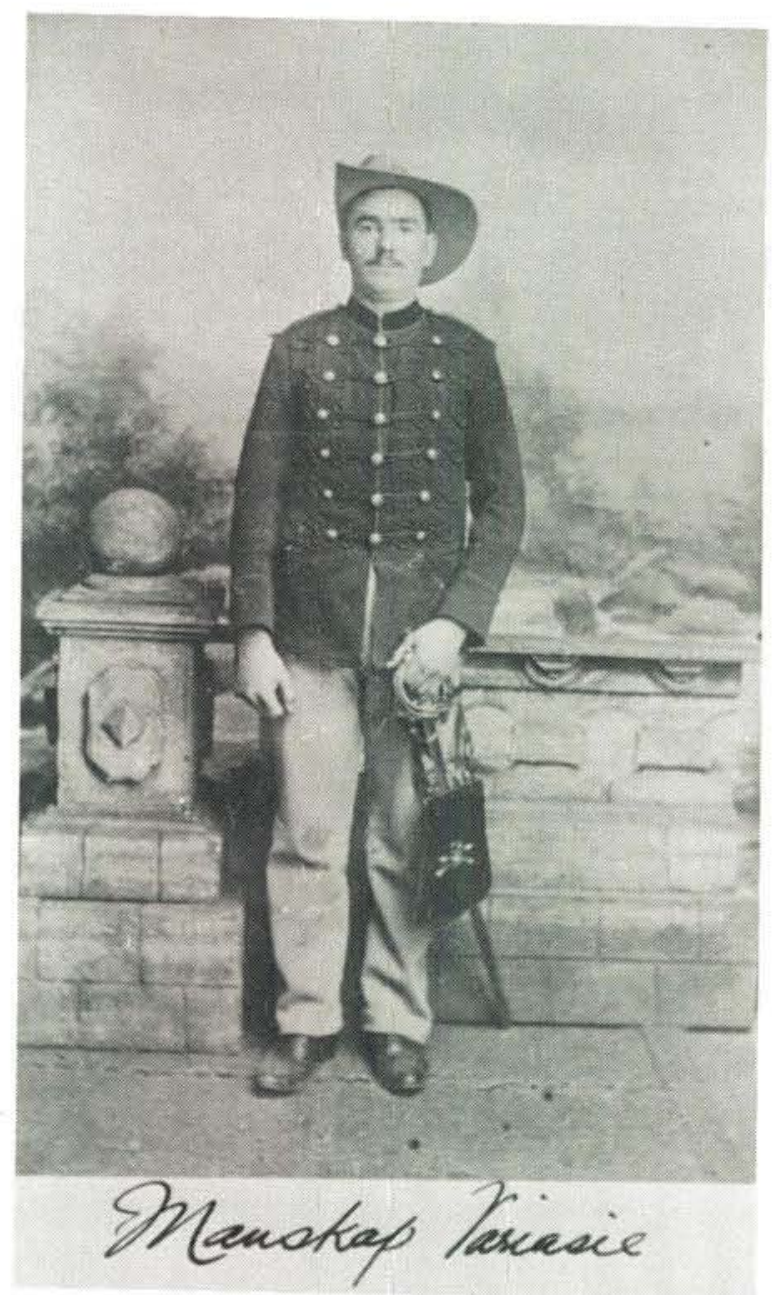

\section{Variasie van manskap se uniform. Let op hoed as hoofbedekking.}

Variation of a troop's uniform. Note the hat as head-gear.

en derde baadjies wat toeknoop tot bo. Die ou republikeinse staatsartillerie se uniforms het self verskil omdat dit in verskillende Europese lande deur verskillende kleremakers vervaardig is.

Die eerste uniforms is nog met ' $n$ swart das en wit hemp gedra. Die baadjie het gelyk soos die gewone seremoniële uniformbaadjie, met in rugslip, maar slegs twee vals bosakke. Daar was geen galonstrepe op die bors nie, maar slegs op die moue. Die tweede en derde toeknoopbaadjies het glad geen sakke gehad nie, want dit sou afbreuk doen aan die patroon van die traseergalon op die bors.

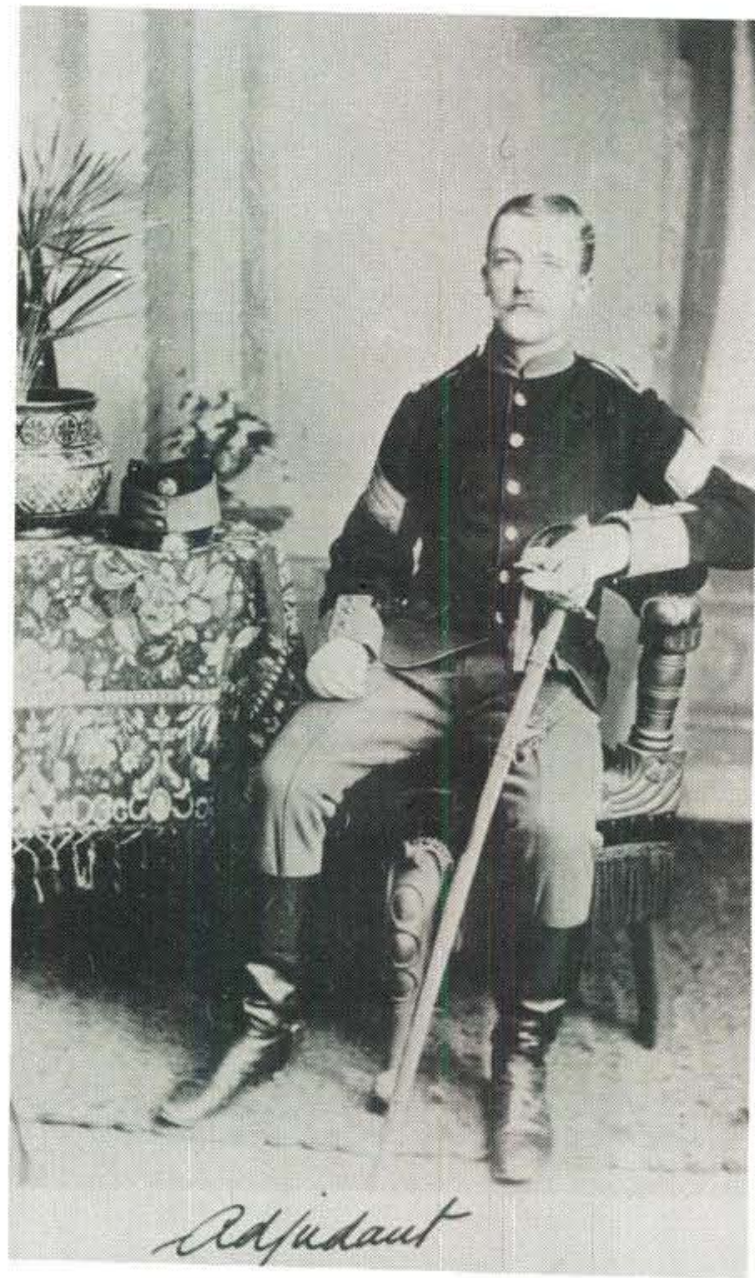

\section{|Adjudant in 'n variasie van uniform met pet as hoofbedekking.}

\section{An adjudant wearing a variation of the uniform and a cap as head-gear.}

Die Staatspresidentswag se uniforms het dus ook sy eie geskiedenis. Die eerste ontwerp is nooit op ' $n$ openbare parade gesien nie, en daar is slegs 125 vervaardig. Die tweede, van 'n groengrys materiaal, se kleur het selfs kritiek van die Staatspresident ontlok, en is aan net een inname dienspligtiges uitgereik. Ook die derde het klein veranderings ondergaan, soos die verandering van geelkoper na vergulde knope, en die insnyding van knoopsgaatjies sodat die knope met splitringe vasgesit kan word om die verwydering vir droogskoonmaak te vergemaklik. 


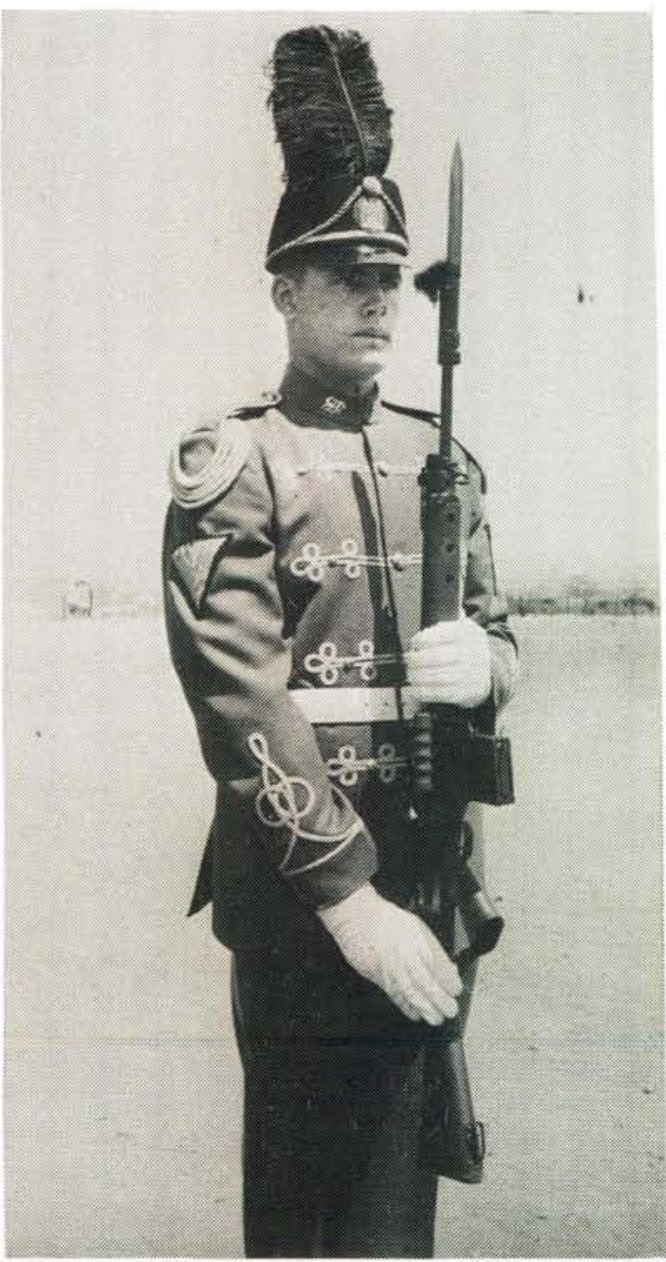

Groen uniform van die Staatspresidentswag met as hooftooisel die swart Leërgimnasiumpet met die Republiekwapen voorop en die swart volstruisvere boop.

Green uniform of the State President's Guard and, as head gear, a black Army Gymnasium cap with the Republic badge on the front, mounted with black ostrich feathers.

Nog 'n poging is aangewend om die outensiteit van die oorspronklike uniforms van die Vrystaatse Artillerie en die van die Staatsartillerie van die Zuid-Afrikaansche Republiek behoue te laat bly. In 1982 het die ou 303-geweer die R1 vervang. Die tradisie van die 303 het herleef en tans kan die wagte met die gewere by die hekke van die Staatspresident se woning gesien word.

Met die verskyning van die tweede ontwerp is goue galon in groot hoeveelhede van Engeland en selfs van Italië ingevoer, want vir elke uniform was daar meer as 10 meter nodig. Die baadjies is by seremoniële geleenthede met 'n gordel gedra, maar andersins is geen gordel gebruik nie. Daar is 'n mansjetkoord van $8 \mathrm{~mm}$ breë goue galonkoord rondom die mou, $40 \mathrm{~mm}$ van die onderpunt met 'n kraaitoon aan die buitekant. Op die kraag is ' $n$ metaalkenteken wat die letters SP vorm, gedra. Die skouer-epoulette is deur goue koord omvleg, met die vier goue galonkoordlusse wat aan weerskante van die epoulette op die bo-arms afhang.

Aanvanklik is gevoel dat die offisiere en manskappe se basiese uniforms dieselfde moet lyk, maar nog voor die eerste openbare optrede is besluit dat die goudgalon op die buitenate van die offisiere en adjudant-offisiere se broeke breër moet wees as die van die onderoffisiere en manskappe.

Al is die Staatspresidentswag ' $n$ leëreenheid, en wel 'n infanterie-eenheid, dra die offisiere in plaas van die tradisionele sabels, kort lugmagdolke. Hulle, die adjudant-offisiere en die onderoffisiere, dra op parade ook die gewone rangtekens, en die bevelvoerder dra op die pet vergulde omboorsel. Die offisiere word van die res onderskei deur hulle gordels. Wat die gordels betref, is in 1967 besluit dat wit gordels vir die dra van bajonette gebruik sou word. Wit handskoene is deurentyd gebruik. Swart skoene is aanvanklik by die uniforms gedra, maar in 1968 is besluit om die skoene met swart stewels te vervang, want die broeke het beter vertoon met stewels. Gewone manskapstewels het grof en lelik vertoon, en daar is op die fyner offisierstewels besluit. Aangesien daar nie sulke stewels beskikbaar was nie, is bruin stewels swart gemaak vir gebruik deur die skildwagte. 'n Bruin skynsel was egter steeds sigbaar, en daar moes dus spesiaal swart stewels vir die SP Wag vervaardig word. Aangesien die Wag soms op reënerige dae op seremoniële parades moes optree, is daar ook gou besef dat daar spesiale reënjasse vervaardig moes word, en dit is reeds in 1968 gedoen.

\section{Besluit om uniform te verander}

Gepaardgaande met die behoefte om die ou groen uniform te vervang, is besluit om dit te verander en iets nuuts en anders in die plek daarvan te stel. Die besluit is egter nie oorhaastig geneem nie, maar het ' $n$ lang aanloop.

\section{0: Komitee vir Ondersoek}

In 1980 verleen die Hoof van die Weermag goedkeuring dat ' $n$ komitee in samewerking met die Hoof van die Leër ondersoek instel na 'n 


\title{
STAATSARTILLERIE VAN DIE ZUID- AFRIKAANSCHE REPUBLIEK
}

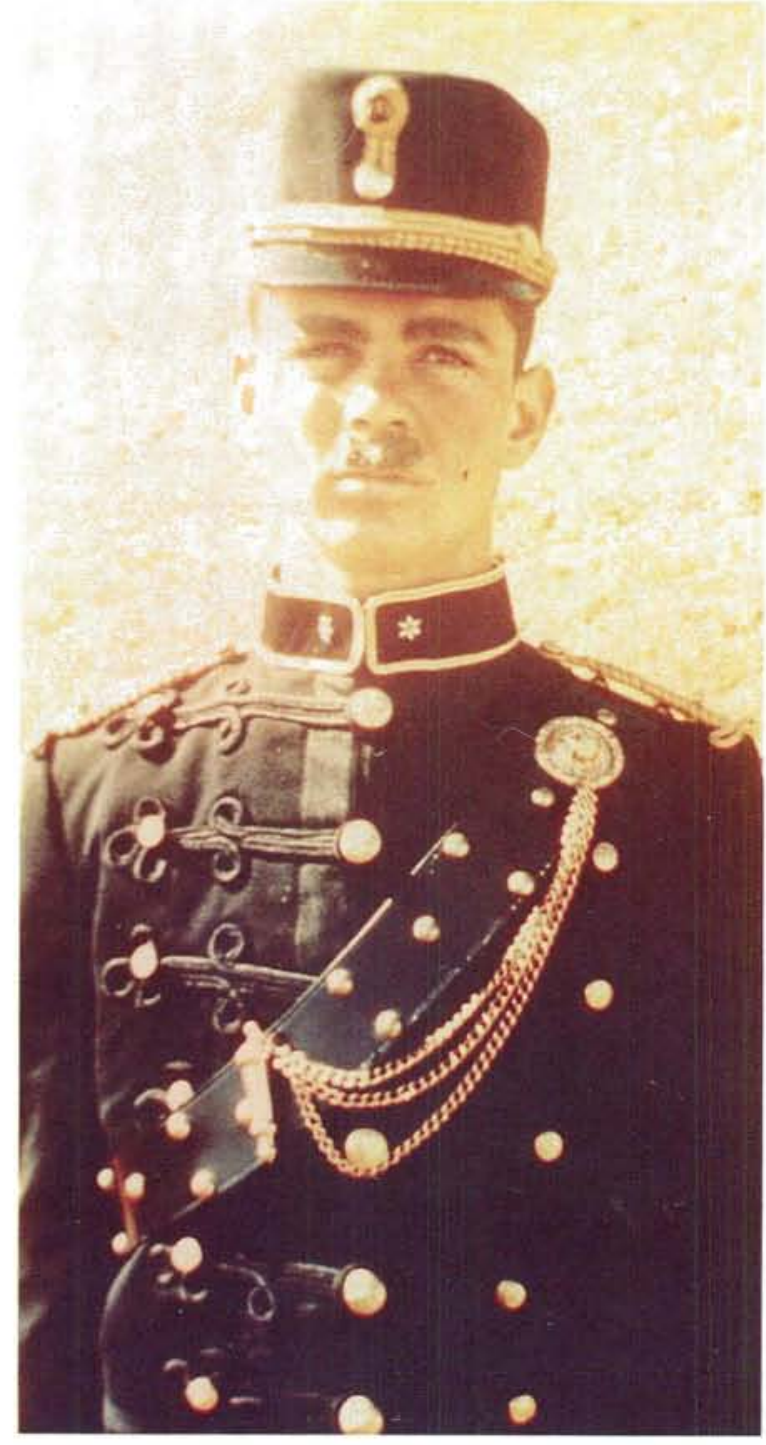

\author{
Donkerblou parade of winteruniform wat \\ met koringblou omgeboor was.
}

Dark blue parade dress or winter dress, with cornflower blue piping.

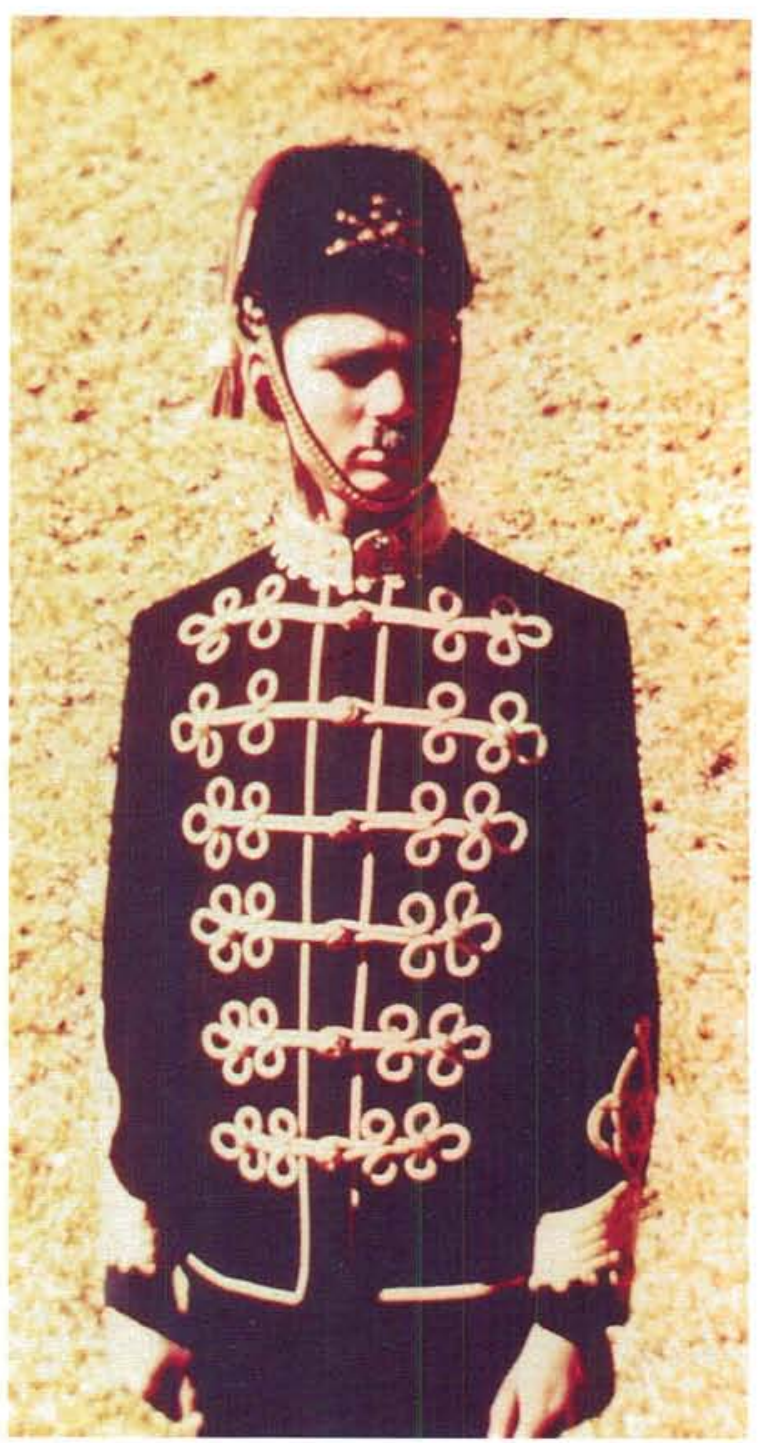

Parade uniform met hee/wat meer versierings.

Parade dress with considerably more decorations. 


\title{
STATE ARTILLERY OF THE ZUID- AFRIKAANSCHE REPUBLIEK
}

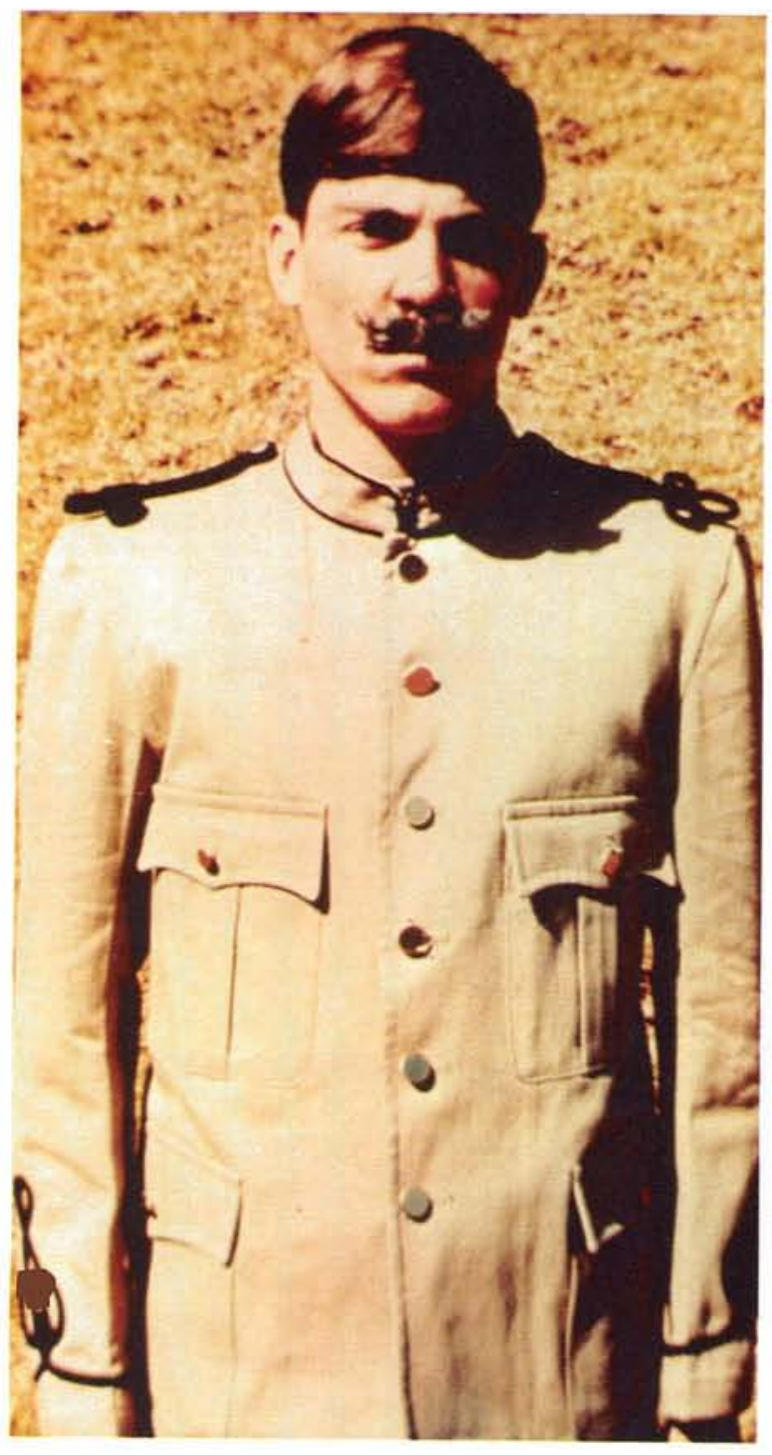

\author{
Somer of velddiensuniform van \\ Staatsartillerie.
}

Summer or field dress of the State Artillery.

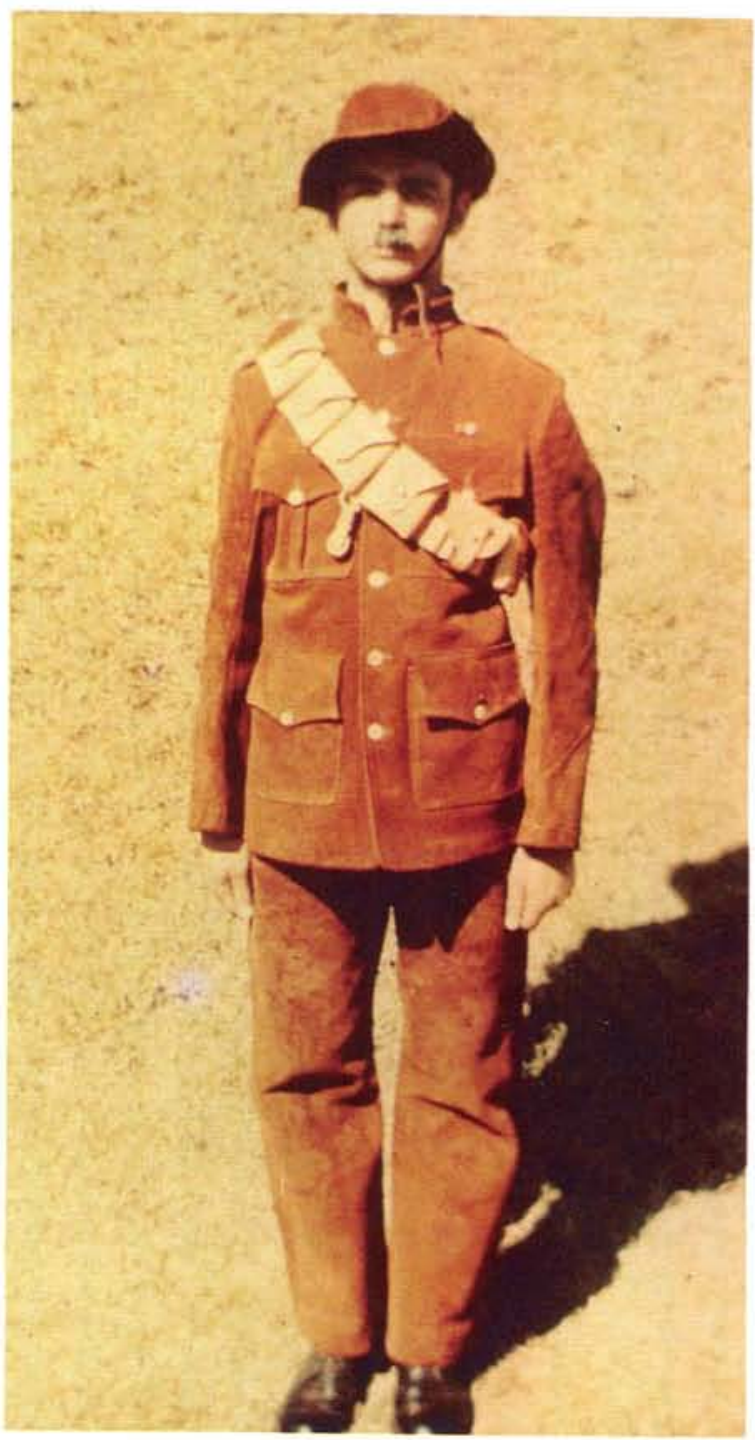

Burgerlike klere wat deur die Staatsartillerie gedra is in die tagtigerjare.

Civilian clothes worn by the State Artillery in the Eighties. 


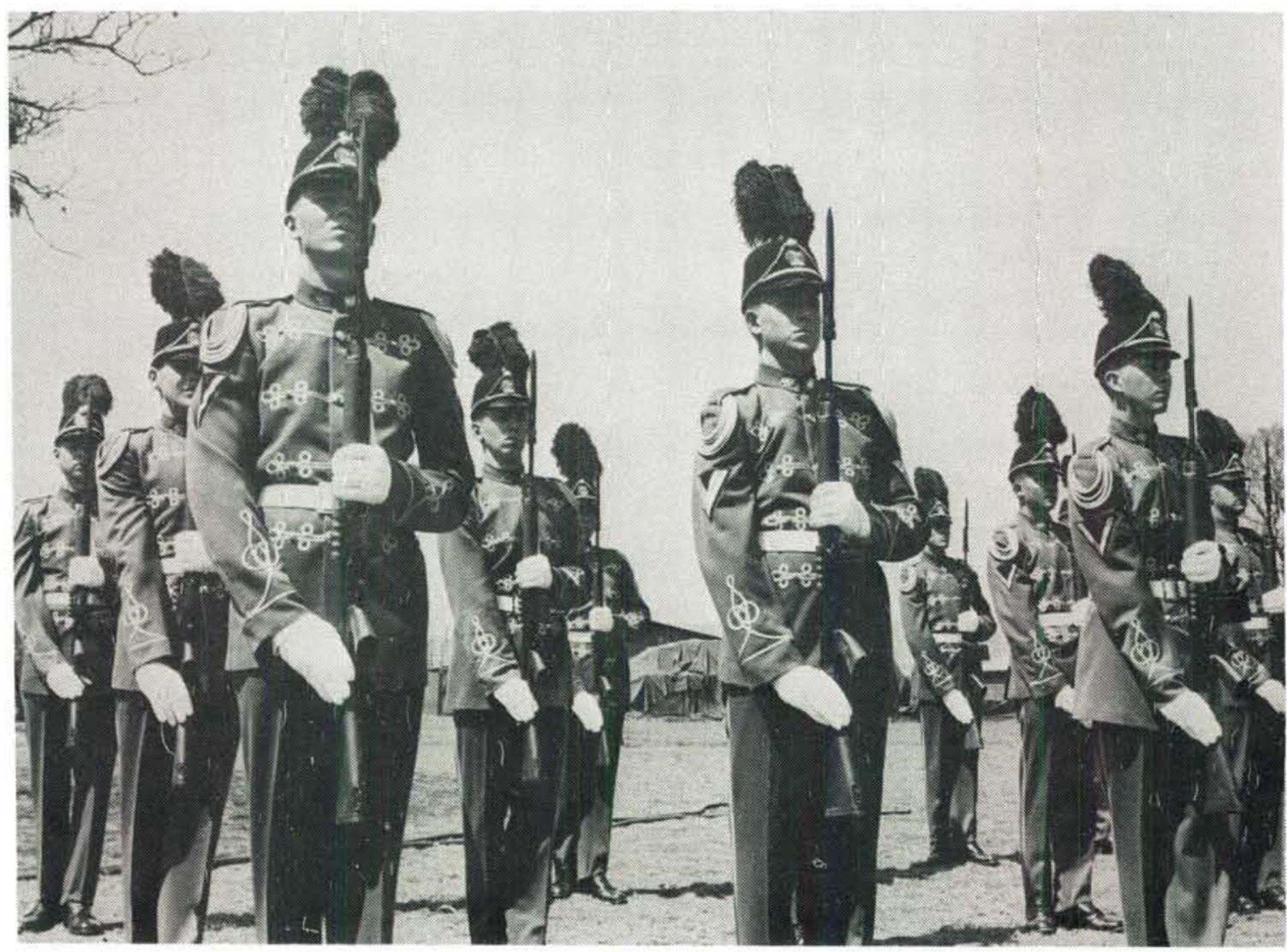

Die Staatspresidentswag in die latere uniform tydens 'n seremoniële geleentheid. Die baadjie is met ' $n$ wit gordel by dié geleentheid gedra.

The State President's Guard wearing the more recent uniform, during a ceremonial occasion. On such occasions, the jacket is worn with a white belt.

geskikte uniform vir die SP Wag. Aangesien die uniforms gedaan was, is besluit om ' $n$ nuwe uniform wat histories verantwoord kon word, te ontwerp.

\section{Blou uniform}

Aanvanklik is besluit dat die husarepet met volstruisvere as hoofdeksel sou bly voortbestaan. Die uniform self sou radikaal verander. Daar is voorgestel dat die uniformbroek blou moes wees, met ' $n$ goue streep langs die kant vir offisiere. Die baadjie sou oranje wees met blou afronding op die moue en kraag en met vergulde knope. Die oranje en blou van die broek en baadjie sou die kleure van die landsvlag verteenwoordig.

Later in 1980 is besluit om die oranje en blou van die baadjie om te ruil sodat die materiaal van die baadjie blou sou wees met oranje koord daarop.

'n Infanterie swaard met koper gespes sou by uniform gedra word.
Teen die middel van die volgende jaar is besluit dat die wit Spesiale Diensbataljon punthelm met penteken gedra sou word. Die lyfband sou in die drie kleure van die landsvlag wees, rangtekens sou met goue koord omboor word en offisiere en onderoffisiere sou 'n sabel dra.

Die nuwe uniform is in Desember 1981 aan die Staatspresident gedemonstreer, deur hom goedgekeur en opdrag is gegee om voort te gaan met die aanskaffing van die nuwe uniform.

\section{4 - Nuwe beslissings}

In Januarie 1984 is die uniform egter deur die Eerste Minister afgekeur en die opdrag is gegee om met iets anders vorendag te kom wat histories verantwoordbaar is in die sin dat dit eg Suid-Afrikaans moes wees. Ook moes daar gepoog word om die landsvlagmotief in die nuwe uniformontwerp in te vleg. Verder was dit belangrik dat die groen uniform vervang moes word deur iets anders wat goedkoper, geriefliker 
en praktieser sou wees as die een wat op daardie stadium in gebruik was.

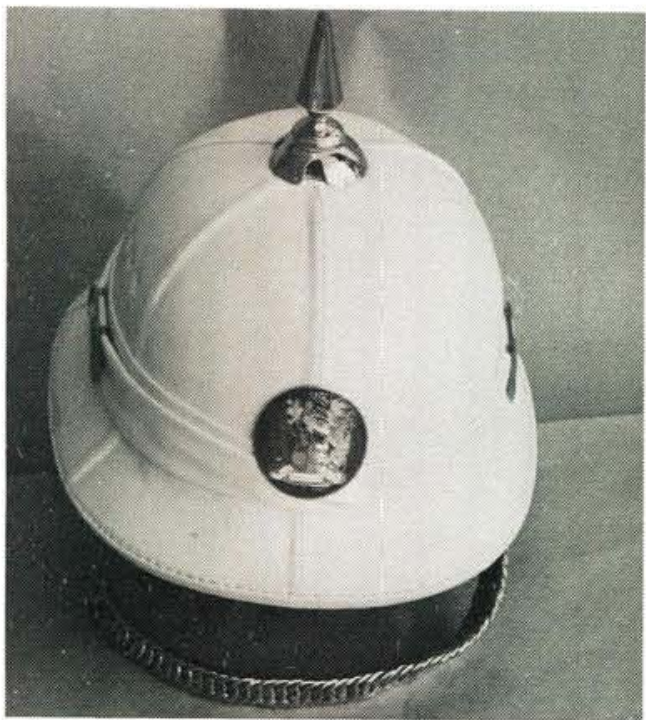

Wit punthelm met penteken. White cork helmet with spike.

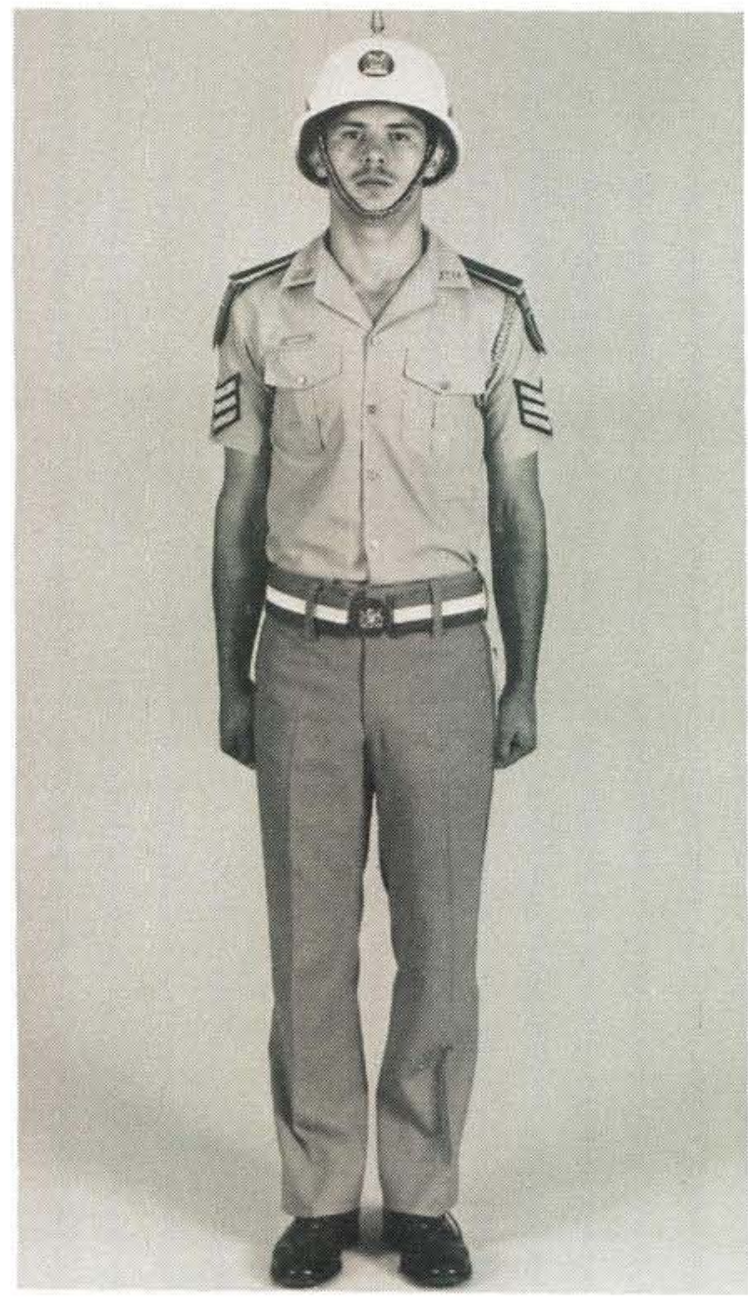

Someruniform van ' $n$ onderoffisier. Summer dress of a non-commissioned officer.

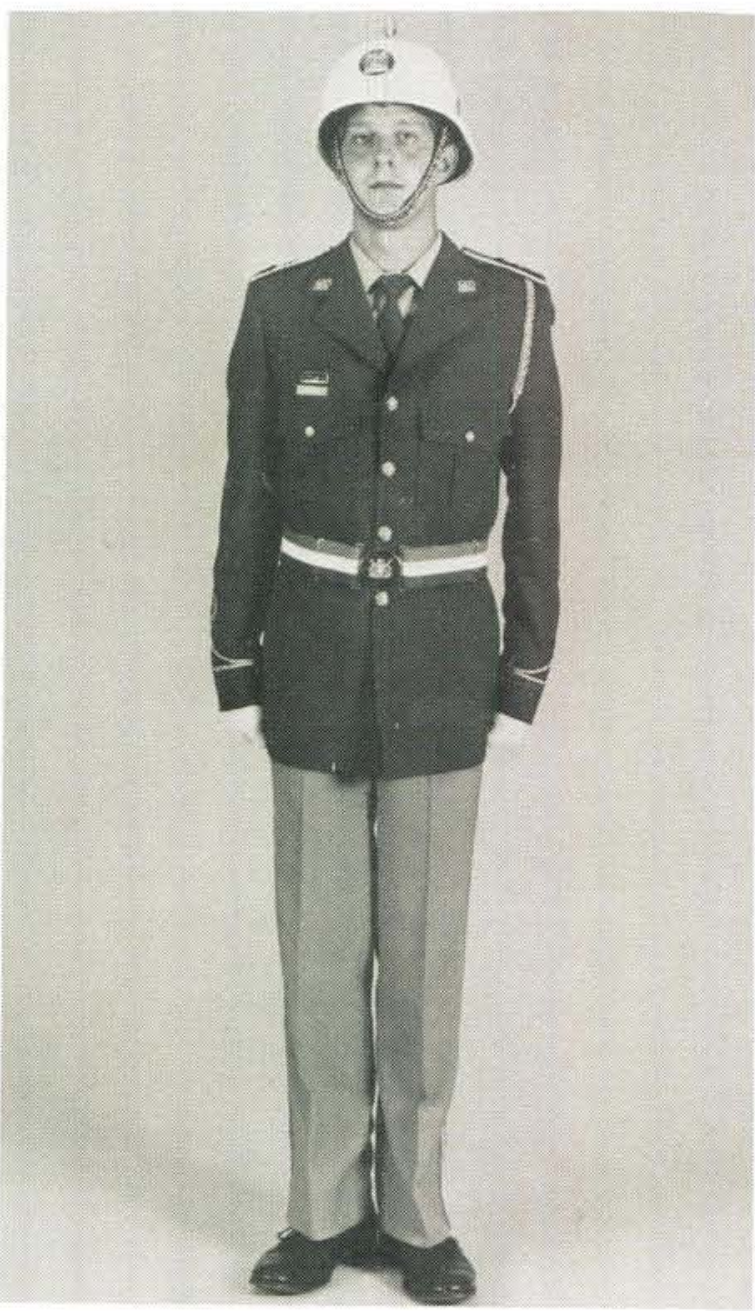

Winter- en parade uniform van 'n offisier.

Winter uniform and parade uniform of an officer.

\section{Redes vir Verandering}

Etlike redes is aangegee waarom dit nodig was om die uniform te verander.

In die eerste plek moes die groen uniform wat in gebruik was en vyf jaar tevore gemaak is, vervang word. Hierdie geleentheid kon dus gebruik word om ' $n$ nuwe en aansienlik goedkoper uniform te ontwerp en aan te skaf.

Die belangrikste bepalende faktor wat die nuwe ontwerp beïnvloed het, is dat die meerderheid items uit die voorraad beskikbaar is.

Aangesien elke kleurmengsel van die groen materiaal ietwat van die vorige verskil het en die kostes nie net die maak van die uniform ingesluit het nie, maar ook die verstellings wat duur en tydrowernd was, is besluit om ' $n$ ander alternatief te vind. Gevolglik is besluit om die SP Wag 


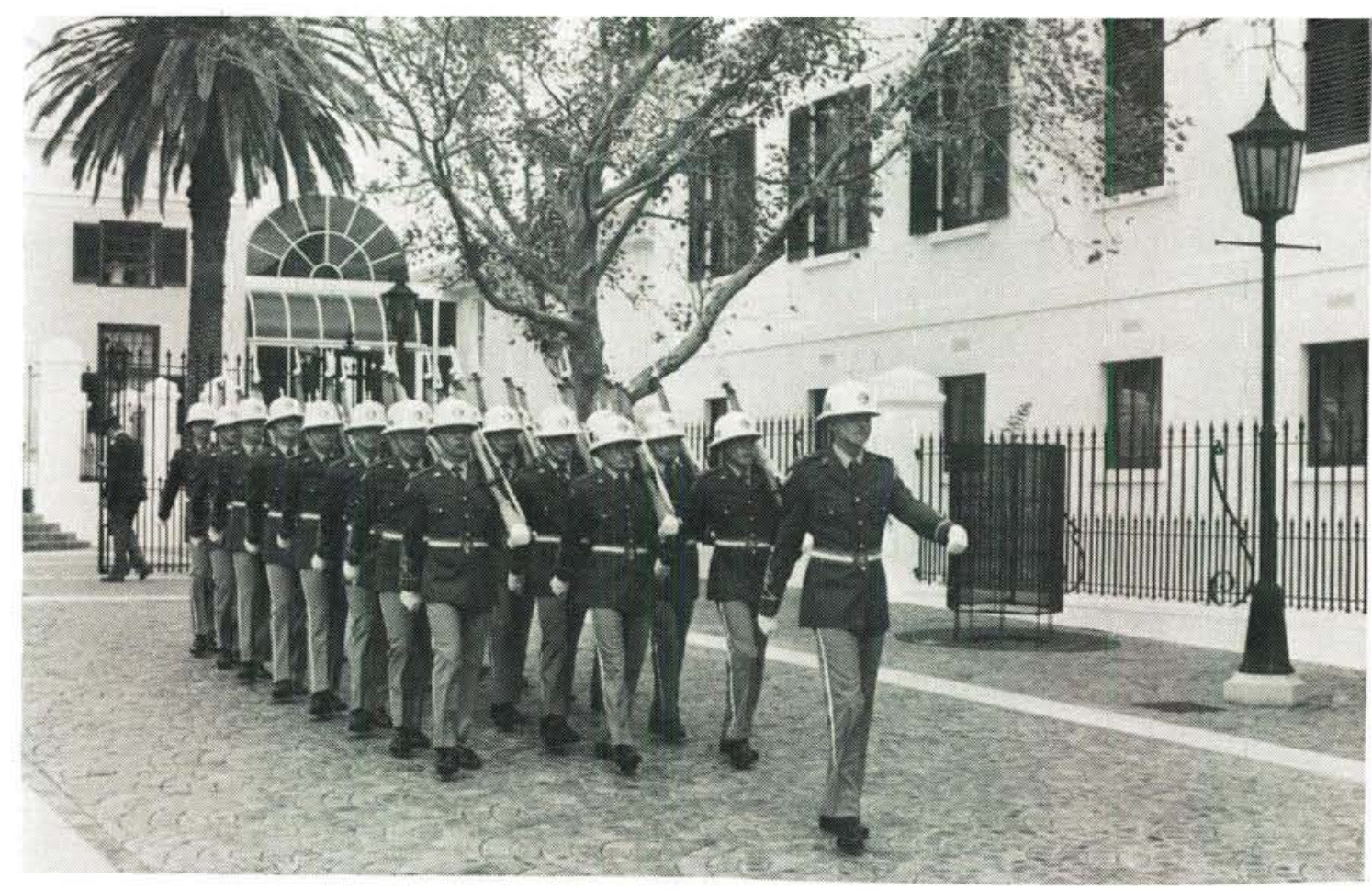

Die Staatspresidentswag op parade in hul nuwe seremoniële uniform.

The State President's Guard on parade in their new ceremonial uniform.

met die standaard Leëruniform uit te reik aangesien die eenheid op die Leër se sterkte is en infanterie opleiding ondergaan sowel as die normale infanterie take uitvoer wat van so ' $n$ eenheid verwag word.

'n Ander bykomstigheid sou by die uniform gevoeg word wat die voorkoms daarvan sou verhoog en die waardigheid van 'n seremoniële uniform vir die Staatspresident Wag daaraan sou verleen.

In die tweede plek is die gesondheidsaspek ondersoek en daar is besluit dat die pet met die volstruisveer nie net duur is om te vervang nie, maar ongesond is. Dit sou deur ' $n$ wit helmet vervang word. Die helmet sou 'n beter lugvloei rondom die draer se kop gee. Met 'n kenband sou dit verder onnodig wees dat die helmet styf moes pas.

In teenstelling hiermee is die swart pet styfpassend om te voorkom dat dit afwaai. Dit veroorsaak dat bloedvate in die kop opswel as dit te lank gedra word en kan floutes tot gevolg hê. Die emalje wapen soos op die pet gedra is, sou ook op die helmet verskyn.
Die helmet as hoofdeksel is deur die weermagte van die Verenigde State van Amerika, Indië, Brittanje, Duitsland en België gedra en in SuidAfrika het die Staatsartillerie van die Zuid-Afrikaansche Republiek, die Unieverdedigingsmag in Suidwes-Afrika en die Spesiale Diensbattaljon (SDB) dit gebruik. Die spits is vir seremoniële gebruik.

Die gesondheidskwessie is verder gevoer deur daarop te wys dat die groen uniform wat van dik materiaal gemaak is, warm in die somer is en nie warm genoeg in die winter is nie. Die hoë kraag is styf en verhinder die bloedvloei as dit te lank gedra word.

Die nuwe uniform sou geriefliker en praktieser wees omdat dit van ' $n$ ligter materiaal gemaak is en vir Suid-Afrikaanse toestande ontwerp is.

Op die buitenate van hul broeke is die kleure van die landsvlag aangebring wat die goue stroke koord van die ou uniform vervang. Hulle gordel is ook in die kleure van die landsvlag en vervang die vroeëre wit seremoniële gordel. Soos vroeër het die gespe die Republiekwapen daarop. Wanneer op parade word die gordel booor die baadjie gedra met ' $n$ skouerkoord oor die linkerskouer. Wit handskoene bly behoue. 
Die nuwe uniform maak voorsiening vir ' $n$ winters- en somersuniform wat by die Suid-Afrikaanse klimaat aangepas is. Al die bykomstighede is geredelik beskikbaar en die koste daarvan is veel minder as dié van die groen uniform.

Derdens is die instandhouding van die nuwe uniform ook makliker en in die lang duur goedkoper omrede die standaard uniform gebruik word en komponente makliker oordraagbaar is. Selfs die helmets kan wanneer dit beskadig is, herstel word.

Nog 'n beswaar teen die ou uniform was dat die goue koord nie geredelik beskikbaar was nie. Dit moes van Frankryk af ingevoer word. ' $n$ Besending vandaar het sowat ses weke geneem om hier aan te kom en baie tyd het in die proses verlore gegaan.

Die pad wat die Staatspresidentseenheid gevolg het om by die uniform van vandag uit te kom, is nie net veelbewoë nie, maar het langs vele historiese omweë geloop. Met die instelling van die Staatspresidentswag in 1967 is 'n uniform, gebaseer op die seremoniële drag van die artil- leriekorpse van die twee 19de eeuse Boererepublieke goedgekeur. In 1985 het die uniform heeltemal verander.

Belangrik is dat dit steeds histories verantwoord kan word, aangesien die helmet herinner aan die van die Unieverdedigingsmag en die SDB en die uniform self die van die SA Leër is met enkele seremoniële stukke daarby.

* Lit-kdr E.M. Meyers, MA (HOD) is verbonde aan die Militêre Informasieburo, SAW.

\section{Bibliografie}

1. H.J. Botha: Die Duitse Aandeel in die Militêre Geskiedenis van SuidAfrika, Suidwes-Afrika, Militaria 2/4, 1970.

2. J.S. du Plessis: Die ontstaan en ontwikkeling van die amp van die Staatspresident in die Zuid-Afrikaansche Republiek (1858-1902), Doktorale Proefskrif, PU vir CHO

3. 0.J.O. Ferreira: Die Staatsartillerie van die ZAR, Militaria 4/3, 1974

4. J. Ploeger: Uit die geskiedenis van die "Corps Staatsartillerie" van die Zuid-Afrikaansche Republiek, Militaria 15/4, 1985.

5. J. Ploeger: Die Bou van die Staatskaserne, Potgieterstraat, Pretoria, Militaria 13/4, 1983

6. SAW Dokumentasiediens: Die Staatspresidentswag 15 Jare, 1982.

7. Die Stadsraad van Pretoria: Die Geskiedenis van die Stad Pretoria, 1955 Pretoria (1855-1955)

8. J.A. Steenkamp: Die Verdedigingstelsel van die Vrystaatse Republiek 1854-1899, Akademiese Verhandeling, UOVS, 1976.

9. T.P.E. Swemmer: Die Geskiedenis van die Vrystaatse Artillerie, Akademiese verhandeling UOVS, 1953. 